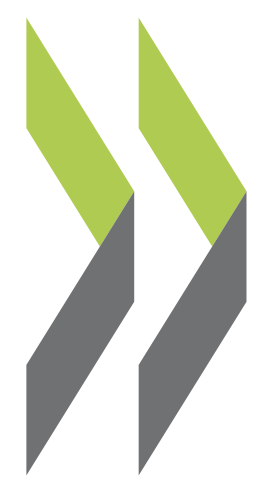

OECD Corporate Governance Working Papers No. 19

\title{
Concerns Related
}

to the Internationalisation of State-Owned Enterprises: Perspectives from

\section{Sara Sultan Balbuena}

\author{
regulators, government \\ owners and the broader \\ business community
}




\section{CORPORATE GOVERNANCE WORKING PAPER SERIES}

OECD Working Papers should not be reported as representing the official views of the OECD or of its member countries. The opinions expressed and arguments employed are those of the authors.

Working Papers describe preliminary results or research in progress by the author(s) and are published to stimulate discussion on a broad range of issues on which the OECD works. Comments on Working Papers are welcomed, and may be sent to corporate.affairs@oecd.org or the Corporate Affairs Division, Directorate for Financial and Enterprise Affairs, OECD, 2 rue André-Pascal, 75775 Paris Cedex 16, France.

OECD Corporate Governance Working Papers provide timely analysis and information on national and international corporate governance issues and developments, including state ownership and privatisation policies. The working paper series is designed to make select studies by the OECD Corporate Governance Committee, OECD staff members and outside consultants available to a broad audience.

\section{OECD CORPORATE GOVERNANCE WORKING PAPERS}

are published on www.oecd.org/daf/corporateaffairs/wp

This document and any map included herein are without prejudice to the status of or sovereignty over any territory, to the delimitation of international frontiers and boundaries and to the name of any territory, city or area.

The statistical data for Israel are supplied by and under the responsibility of the relevant Israeli authorities. The use of such data by the OECD is without prejudice to the status of the Golan Heights, East Jerusalem and Israeli settlements in the West Bank under the terms of international law.

(c) OECD 2016

You can copy, download or print OECD content for your own use, and you can include excerpts from OECD publications, databases and multimedia products in your own documents, presentations, blogs, websites and teaching materials, provided that suitable acknowledgment of OECD as source and copyright owner is given. All requests for commercial use and translation rights should be submitted to rights@oecd.org. 


\title{
Concerns Related to the Internationalisation of State-Owned Enterprises
}

\author{
PERSPECTIVES FROM REGULATORS, GOVERNMENT OWNERS \\ AND THE BROADER BUSINESS COMMUNITY
}

\author{
by \\ Sara Sultan Balbuena*
}

\begin{abstract}
The rise in state-owned enterprises (SOEs) as growing actors in international trade and investment has received renewed attention in recent years, not least due to controversy that has arisen over SOE foreign investments. This has raised the profile of these issues with policy makers and tilted much of the public debate in one direction. Some concerns revolve around the intentions of these companies, or any potential competitive distortions that could be caused by them which would differentiate them from privately-owned enterprises operating under like circumstances. With a view to keeping the trade and investment environment open, this paper draws attention to particular perceptions of concerns or challenges that arise when SOEs internationalise. Although perceptions are not verifiable facts, they reveal important trends that may inform the debate and shape future government policies towards foreign trade and investment by SOEs. The information in the report is primarily drawn from findings emerging from a three-part perception-based OECD survey addressed to public officials responsible for enterprise ownership, competition enforcement, investment regulation and trade policy in addition to departments of government with broader responsibility for the enterprise and competition landscape, and/or cross-border trade and investment regulation.
\end{abstract}

Authorised for publication by Adrian Blundell-Wignall, Director, OECD Directorate for Financial and Enterprise Affairs

JEL Classifications: F21, F23, G3, G30, G38, G39, L32, L33

Keywords: Corporate governance; investment policy; competitive neutrality; state-owned enterprise; trade policy; national security; level playing field; investment review; cross-border trade and investment; international investment; competition; competitive markets; international investment.

Sara Sultan Balbuena works for the Corporate Affairs Division of the OECD Directorate for Financial and Enterprise Affairs. This work benefited from inputs from an informal taskforce of delegates and substantive input from the OECD project team including: Hans Christiansen (Corporate Affairs Division), Mike Gestrin, Carly Avery and David Gaukrodger (Investment Division), Antonio Capobianco and Mona Chammas (Competition Division), Przemyslaw Kowalski and Kateryna Perepechay (Trade Directorate). 


\section{TABLE OF CONTENTS}

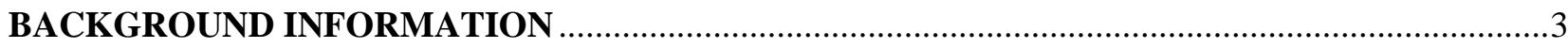

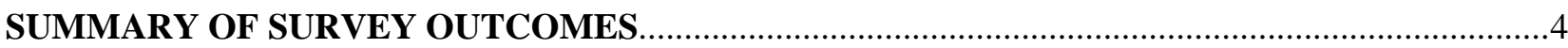

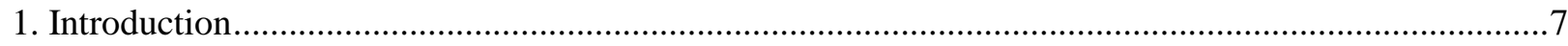

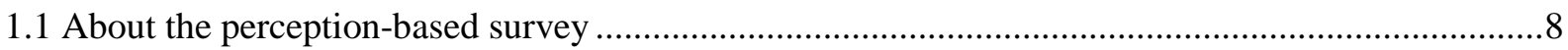

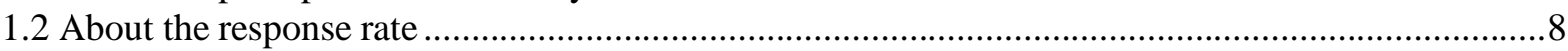

2. Concerns of host country policy-makers when foreign SOEs seek to invest in their jurisdiction ............9

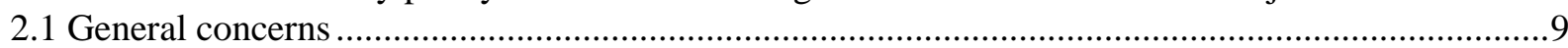

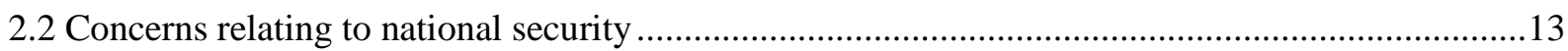

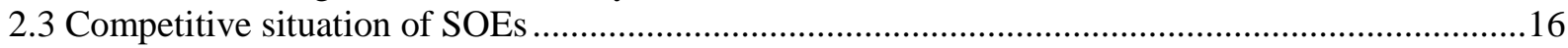

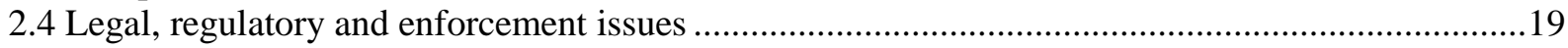

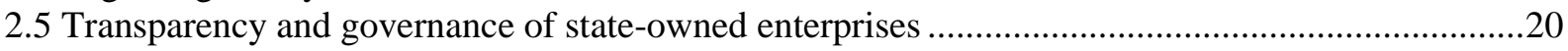

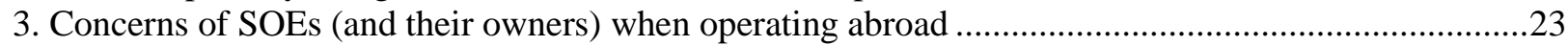

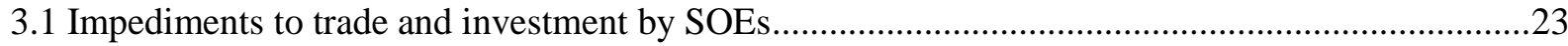

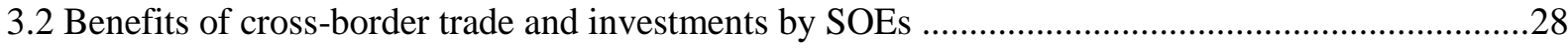

4. Concerns related to international trade of goods and services involving SOEs ....................................31

4.1 Competition with foreign SOEs when engaging international trade

(covering both the goods and services markets) ................................................................................

4.2 Discrimination of SOEs when engaging in international trade

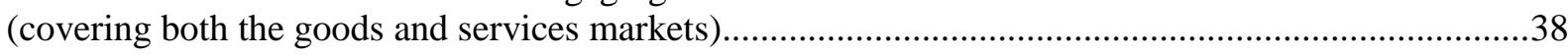

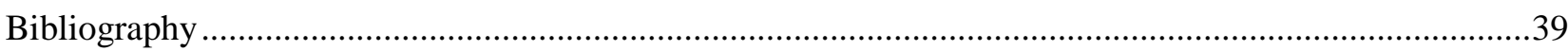

Appendix: Survey Questionnaire on State-Owned Enterprises in the Global Market Place ................41

\section{Figures}

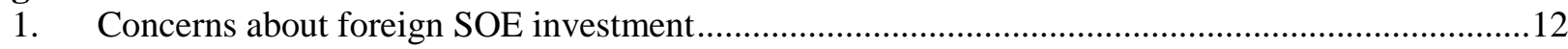

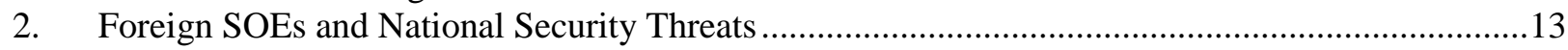

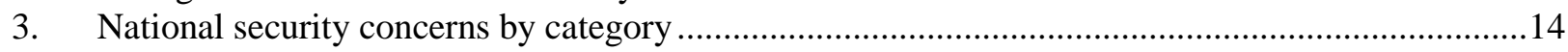

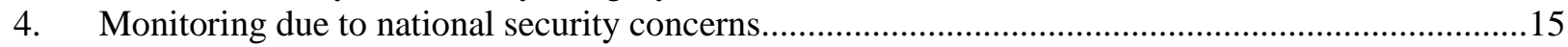

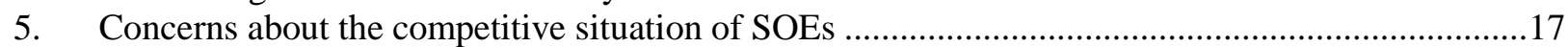

6. Unfair competitive advantages due to public ownership .............................................................18

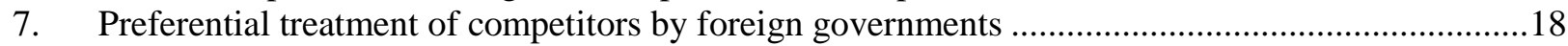

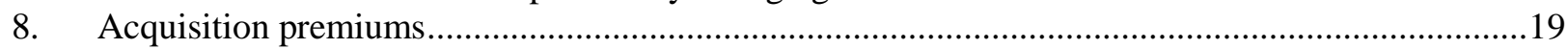

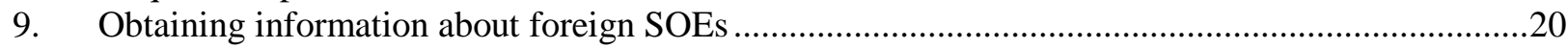

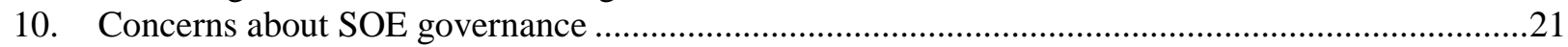

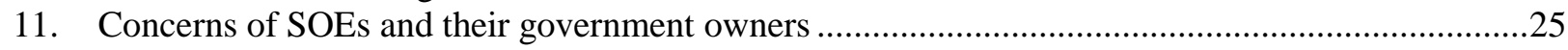

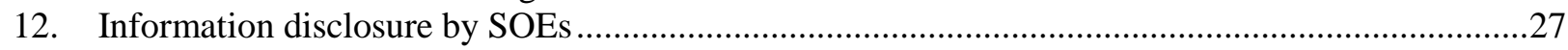

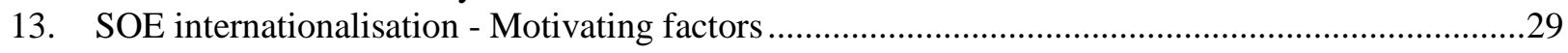

14. Competition with foreign SOEs -Trade concerns......................................................................32

15a. Preferential treatment of SOEs - Impact on international trade of goods and services ....................34

15b. Preferential treatment of SOEs - Impact on international trade of goods and services ......................35

16. Advantages granted by foreing governments to or via SOEs - Level of government ......................37

17. Advantages granted by foreign governments to competitors - Level of government..........................37 


\section{BACKGROUND INFORMATION}

This Working Paper emanates from a multidisciplinary project at the OECD called "State-Owned Enterprises (SOEs) in the Global Marketplace" which aims to foster an inclusive dialogue among stakeholder across the competition, investment, corporate governance and trade policy communities. The project examines the effects and regulatory challenges arising from the internationalisation of SOEs through foreign trade and investment. The project's objective is to arrive at a consensus among OECD and a large number of partner countries on the following two issues: (1) do specific concerns about maintaining a level playing field arise when SOEs operate across borders and, if so, how could these be addressed; and (2) how to ensure that the international trade and investment environment remains open and welcoming to foreign SOEs.

The project has been informed by the May 2014 OECD Ministerial Meeting, when ministers from OECD and partner countries received a progress report on levelling the international playing field between public and private business. This horizontal initiative involves, a broad range of OECD policy forums, including, notably the Freedom of Investment Roundtable, the Corporate Governance Committee (and Working Party on State Ownership and Privatisation Practices), as well as the Trade and Competition Committees.

The information in the report is primarily drawn from findings emerging from a three-part perceptionbased survey addressed to public officials, which was conducted from February through July 2015, circulated to delegates of the project's participating bodies. It is further supplemented with findings emerging from the "OECD Business Survey on State Influence on Competition in International Markets" conducted in 2014; interviews conducted with delegates and representatives of the business community; and desk research. An earlier draft was shared among participating Committees and benefited from comments from an informal cross-Committee Taskforce of delegates. In addition, the survey and paper benefited from substantial input from the project team in the Directorates for Financial and Enterprise Affairs (Corporate Affairs, Investment and Competition Divisions) and Trade Directorate (Development Division). For more information on the project, readers are invited to visit the OECD website: www.oecd.org/daf/ca/achievingcompetitiveneutrality.htm 


\section{SUMMARY OF SURVEY OUTCOMES}

This Working Paper is based on a perception-based survey addressed to government authorities responsible for enterprise ownership, competition enforcement, investment regulation and trade policy in addition to departments of government with broader responsibility for the enterprise and competition landscape, and/or cross-border trade and investment regulation. The survey, carried out from February - July 2015, was answered by 17 jurisdictions, representing mainly OECD member jurisdictions. The results are intended to serve as the basis for consultations with Members and stakeholders on the main challenges and concerns related to the internationalisation of SOEs. Although perceptions are not verifiable facts, they reveal important trends that may inform the debate and shape investment and trade policies towards stateowned enterprises in the future.

The main outcomes of the survey are summarised as follows:

- Public ownership may be a source of concern, but not for all policy communities.

- Preferential treatment received by and via SOEs is considered to impact the playing field.

- There are limited concerns over national security, but mainly focused on critical infrastructure and strategic technologies/resources where SOE foreign operations can be distinguishably large.

- SOE governance and transparency practices; and access to information on SOE operations were considered important.

- No perceivable differences in the motivations and challenges faced by SOEs, as compared with private companies.

Perceived concerns related to public ownership and preferential treatment in the domestic marketplace. With regard to whether state-ownership can exacerbate concerns about market distortions in the global marketplace the survey yielded mixed results.

- Investment policy perspectives. From the investment regulation perspective, it would appear that public ownership is not a defining factor (86 per cent of respondents consider that SOE investments represent the "same level of threat" compared with privately-owned firms). This may explain why a majority of respondents indicate that foreign SOEs are not subject to more intensive monitoring by investment regulators in their jurisdictions. However, there were some or strong concerns regarding SOEs position in the domestic marketplace (77 per cent) and whether they are subject to competition enforcement. The main areas identified to be of some or strong concern were i) preferential financing (77 per cent), ii) outright subsidies (61 per cent); and, iii) regulatory exemptions (58 per cent).

- Trade policy perspectives. From a trade perspective, it would appear that public ownership is a more defining factor with regard to distortions in the marketplace. Over 80 per cent of respondents consider that SOEs are favoured by their governments (emanating more often than not from the local or sub-national governments), and more than 46 per cent report that SOEs are 
more prone to receiving advantages compared with privately-owned enterprises (46 per cent). 73 per cent of respondents consider that such benefits can have an impact on international trade in goods and services. All forms of preferential treatment cited in the survey were selected to be of "some" or "strong" concern in both the goods and services markets. Finally, advantages granted by SOEs were also considered to impact the playing field.

- SOE (or government owner) policy perspectives. From an SOE (or government owner) perspective, most respondents do not consider that particular hurdles in their overseas operations are related to their public ownership status. At the same time, respondents report that their overseas operations can be met by recipient countries with political unease due to i) the presence of the government as a shareholder; and ii) perceived competitive advantages.

\section{Perceived concerns related to national security or the competitive situation of SOEs}

- Investment policy perspectives. Despite a low level of overall concern with respect to foreign SOE investment, 30 per cent of respondents report national security concerns. These concerns appear to have a strong sectorial element and may be exacerbated by foreign SOE investment in a small-sized economy. In particular, investments in critical infrastructures (energy, communication or heavy industry) and strategic technologies or natural resources were identified of strong concern (over 60 per cent of respondents). Concerns related to espionage were of reported by a smaller margin of respondents, and vary according to the country of origin of the investment. In general this finding would tend to support the hypothesis that regulators place more weight on "economic" concerns than other more onerous ones; and the sectorial bias may reflect trends in international M\&A activity by SOEs.

- Concerns about preferential treatment do not translate into any perceived anti-competitive conduct by SOEs (i.e. with regard to anti-competitive mergers, cartels, monopolisation or abuses of dominance). Moreover, respondents do not perceive SOEs to be over or under paying for their acquisitions - a finding supported by recent empirical evidence. However, and perhaps counterintuitively, this does not preclude that respondents were not concerned about preferential financing and subsidies provided to SOEs (see also above).

- Trade policy perspectives. Advantages granted via SOEs appear to be a strong preoccupation for the trade policy community, especially in the goods markets, even if trade disciplines are stronger in this area. These advantages can include granting cheaper loans (upstream advantages) and or providing access to goods and services at favourable prices. The forms of treatment (granted to SOEs) with the "strongest" reported impact on competition included: preferential treatment in public procurement; price support; grants/direct payments; and tax concessions.

\section{Perceived concerns about SOE governance and transparency practices; and access to information.}

- Investment policy perspectives. 80 per cent of respondents indicate some or strong concerns about political interference in SOE' commercial operations. This may explain why regulators consider that accessing information on foreign SOE (company-specific objectives, state ownership policy, annual reports, etc.) is important to ensure that i) SOEs operate independently and autonomously from the state; and ii) to quell any potential concerns regarding non-commercial objectives underpinning SOE operations in a foreign jurisdiction. As a corollary issue, the risks of SOE being embroiled in foreign corrupt practices also ranked high among concerns of regulatory authorities. 
- $\quad$ Trade policy perspective. From a trade policy perspective, clarity around corporate governance practices and non-commercial objectives were considered important for SOE owners to consider. On the contrary, respondents do not perceive any observable differences in their ability to determine preferential treatment among SOEs and private firms. Whether this can be attributed to adequate access to information and transparency around SOE operations is left an open question.

- SOE (or government owner) policy perspectives. SOEs (and their government owners) report that their overseas operations are met with political unease due to i) the presence of the government as a shareholder; and ii) perceived competitive advantages. This finding supports the relatively high degree of concern about political interference reported by investment regulators. In order to mitigate these concerns, SOEs report positive outcomes when information is provided on the company's commercial objectives; governance structures and ownership mechanisms; in addition to disclosing financial and non-financial information. Respondents also consider their commitments to responsible business conduct to be an important factor in facilitating SOE investments.

\section{Perceived motivations and challenges related to SOE overseas operations}

- SOE (or government owner) policy perspectives. The main motivations behind cross-border trade and investment reported by SOEs (and government owners) are related to i) profit generation; ii) commercial/industry specific factors; iii) and, broader internationalisation strategy. SOEs and their owners report that their overseas operations can contribute to employment creation and the development of new industries.

- Most responding jurisdictions (either SOEs or government owners), report concerns faced in their overseas operations when it pertains to i) restrictions imposed by investment or trade agreements ${ }^{1}$, ii) treatment in administrative or regulatory procedures; ii) where specific industry restrictions may exist; and, iv) treatment in public procurement processes. However there were no perceivable differences in the motivations and challenges faced by SOEs, as compared with private companies.

\footnotetext{
${ }^{1}$ Specific provisions relating to state-owned enterprises are increasingly being made reference to in investment or trade agreements. These agreements may set out mutual commitments and expectations (i.e. nondiscrimination or disciplines on SOE governance).
} 


\section{Introduction}

It is well documented that international trade and investment by enterprises (regardless of ownership) is an important contributor to growth, insofar as such commerce does not pose any national security threats, or undermine public or economic benefits to the recipient country. In "return" regulators also expect a certain level of behaviour by firms and multinational enterprises, as part of a broader commitment to keep the international investment environment open, as is manifested for example in the $O E C D$ Guidelines for Multinational Enterprises (OECD, 2011), the "Santiago Principles" (IWG, 2008), the 2008 OECD Declaration on Sovereign Wealth Funds and Recipient Country Policies (OECD, 2008a), and the 2009 OECD Guidelines for Recipient Country Investment Policy Related to National Security (OECD, 2009)and other multilateral/mutual commitments.

The purpose of the Working Paper and survey on which it is based is to draw attention to particular perceptions of concerns that arise when SOEs internationalise. There are a few trends that warrant the focus of this analysis:

- Firstly, the global economy has witnessed an increase in SOEs' international investment activity (including, but not limited to mergers and acquisitions - M\&As) over the past decade, and such investment is projected to be on the rise; trade and investment tends to be focused in "sensitive" or strategic sectors where state ownership is widespread (see OECD, 2015d).

- Secondly, recent attention by policy-makers, such as through strengthened reviews of stateowned companies under investment reviews or screenings, has generated further interest as to the intentions of SOE, any potential competitive distortions that could be caused by them through preferential treatment at home, or through the pursuit of objectives other than commercial ones which would differentiate them privately-owned enterprises operating under like circumstances.

- Thirdly, recent negotiations of multilateral investment and trade agreements have included reference to state-owned enterprises, and put forward additional commitments relating to the expectations of state-owned enterprises operating in the marketplace.

- Finally, significant coverage of these trends in the press, especially where controversy has arisen over SOE investments, has drawn attention to the issue of state-owned enterprises, which has not only raised the profile of concerns with policy makers but has also had the impact of tilting much of the public debate in one direction - mainly focused on the concerns with SOE internationalisation.

By examining the issue from the perspective of "concerns" the Working Paper and the survey on which it is based do not intend to rationalise any of one-sided public debate on the topic, but to foster a discussion in the broader OECD context as to the extent to which such concerns are reflected in the thinking of policy-makers. For this reason, the survey does not only ask questions of regulators where foreign SOE may be active in their marketplace, but also asks questions of government owners of SOEs with foreign operations. In this way, it can serve as a useful consultation tool within concerned OECD policy communities, and to inform the debate for next steps in the project on "SOEs in the Global Marketplace." 


\subsection{About the perception-based survey}

The survey, conducted from February through July 2015, was addressed to government authorities responsible for enterprise ownership, competition authorities, investment regulators and trade authorities in addition to departments of government (e.g. ministries of finance and/or industry) with broader responsibility for the enterprise and competition landscape, and/or cross-border trade and investment regulation. The survey consisted of 44 questions, asking about perceptions (not verifiable facts) covering the following three main areas (see also Appendix):

- $\quad$ Part A addressed concerns of host country policy-makers when foreign state-owned enterprises (SOEs) seek to invest in their jurisdiction. This part of the survey asked about concerns relating to national security; competition policies; legal, regulatory and enforcement issues; and the transparency and governance of state-owned enterprises (see Appendix).

- $\quad$ Part B addressed concerns of SOEs (and their owners) when operating abroad. This part of the survey asked about implements to trade and investment by SOEs; and the benefits of cross-border trade and investments by SOEs.

- $\quad$ Part $\mathrm{C}$ addressed concerns related to international trade of goods and services involving SOEs. This part of the survey asked about concerns relating to competition with foreign SOEs when engaging international trade (covering both the goods and services markets); and concerns about discrimination of domestic SOEs when engaging in international trade (covering both the goods and services markets).

\subsection{About the response rate}

As of end-August 2015, the survey has received full or partial responses from a total of 17 jurisdictions including: Australia, Austria, Chile, Czech Republic, Estonia, European Commission, Finland, Israel, Japan, Lithuania, Mexico, Portugal, Slovak Republic, Spain, Sweden, Switzerland, and Turkey. ${ }^{2}$ An additional four jurisdictions officially declined to respond to the questionnaire including: Costa Rica, France, Germany, and the United States. The reasons for decline varied by jurisdiction. The large countries declined to participate either because of confidentiality concerns related to national-security related questions, or because the questions aim so broadly that it would have involved an extensive interagency procedure. Other reasons to account for include: non-applicability, confidentiality concerns, political sensitivity and reservations regarding the design of the questionnaire.

The Working Paper is further supplemented with findings emerging from the "OECD Business Survey on State Influence on Competition in International Markets" conducted in 2014; interviews conducted with delegates and representatives of the business community; and desk research. An earlier draft was shared among participating Committees and benefited from comments from an informal crossCommittee Taskforce of delegates. In addition, the survey and paper benefited from substantial input from the project team in the Directorates for Financial and Enterprise Affairs (Corporate Affairs, Investment and Competition Divisions) and Trade Directorate (Development Division).

The remainder of this report is divided into three parts, following the format of the original survey: Section two covers concerns related to investment regulation; section three covers concerns of government ownership bodies; and section four covers concerns related to trade regulation.

\footnotetext{
${ }^{2}$ The Swiss and Turkish authorities submitted more than one reply to certain questions under Part B.
} 


\section{Concerns of host country policy-makers when foreign SOEs seek to invest in their jurisdiction}

This section of this working paper addresses responses to the survey relating to concerns of host country policy-makers with regard to foreign $\mathrm{SOE}$ operations in their jurisdiction. The section is organised around five main areas of concern that were responded mainly by government authorities responsible for the regulation of international investment. The sections covers general concerns related to international investment (section 2.1); concerns related to national security (section 2.2); concerns related to the competitive situation of SOEs (section 2.3); concerns regarding the application of legal and regulatory frameworks, and their enforcement vis-a-vis foreign state-owned market actors (section 2.4); and, concerns related the transparency and governance of SOEs (section 2.5).

\subsection{General concerns}

Part of the concern related to the internationalisation of SOEs, for regulators and private competition, is that SOEs may not behave like private firms, and decisions may not be driven by business objectives and the underlying creation of economic value. Instead, SOEs (even if they enjoy managerial autonomy and limited governmental interference) have to factor in political goals and non-business motivations of their state owners (Cuervo, 2014). Moreover, SOEs in some jurisdiction may legitimately depart from commonly accepted commercial practices in their domestic SOE sectors to remedy market imperfections, to protect natural or legal monopolies; to carry out public policy obligations, industrial policy or national development strategies; to provide public services and, to protect fiscal revenues, local employment, etc. When they internationalise, some of the concerns relate to spill overs from a privileged position in the home market in to the SOEs international operations. These concerns are not necessarily limited to SOEs, they can also relate to the behaviour of privately owned firms in the host market.

Apart from the above-cited concerns, a more onerous concern is that foreign governments may purposefully support the internationalisation of their SOEs in pursuit of political or strategic goals, regardless of their impact on the global marketplace. These concerns are more onerous because they challenge commonly accepted principles of international competition and of the multilateral trading and investment system; and such transactions, depending on their scale and recurrence, can have an impact on global resource allocation.

The following concerns were identified:

- National security. This is taken to represent all security-related concerns regarding foreign direct investment, but can range from SOEs used for espionage; denial of services or sabotage in case of conflict; erosion of strategic advantages; acquire of strategic assets.

- Public interest. This taken to represent concerns that could undermine public interest in the host country. For example, if a foreign entrant operated at lower environmental, health, and safety standards.

- Net economic benefits. This can broadly define any reason for reviewing or impeding inward investment (e.g. net benefit or economic benefits criteria) other than those related to safeguarding national security. A number of countries have taken measures, in national legislation as well as, sometimes, in international investment agreements to close certain economic sectors to 
foreign participation, or make foreign participation subject to prior agreement. An example often cited, is the loss of local employment.

- Protect national champions. Closely related to "net economic benefit", this category specific identifies concerns related to undermining the competitive situation of national champions. An example often cited is the loss of economies of scale or loss of proprietary technologies to foreign competition. ${ }^{4}$

- Ad hoc political intervention. This relates to the risk that corporate insiders or majority shareholders may use their powers to impose decisions on any given company that are not in the objective commercial interest of the company and its shareholders. In the case of SOEs, would consist of ad hoc political interference by the government owner in company operations, which could be potentially distortive. A common example cited is concern is the government intervention in the case of crisis response. ${ }^{5}$

- Competition enforcement policies. This concern relates to the possibility that a foreign SOE is not subject to strict completion law enforcement in home country; which, if the SOE benefits from a privileged position in the home country, could give rise to potential for competition distortions in host country markets.

- Maintain a level playing field. The overriding economic concern about the operations of SOEs in competition with private companies is almost invariably a fear that the SOEs are subsidised, or otherwise favoured by their state owners (tax exemptions, favourable access to finance, etc.), to the point where they enjoy an unfair advantage that can carry over into their international operations.

- Insufficient information about entrants. If SOEs are privy to privileged information from governments, including classified intelligence, confidential cabinet decisions, etc. then this could be perceived as an unfair advantage and can have an impact on market confidence. This entry also relates to a general lack of information or transparency on the objectives of the SOE which might impact its cross-border investments.

- "Re-nationalisation" of privatised firms. Where the incumbent operators' utilities or network industries have in the past been privatised, the privatisation process was sometimes not uncontroversial with the government making its case mostly by arguing that a transfer to the private sector would increase efficiency and lower the user costs. The transfer back to public ownership through takeover by a foreign SOE inevitably gives rise to controversy.

\footnotetext{
${ }^{3}$ An overview of such measures among adherents to the OECD Declaration on International Investment and Multinational Enterprises can be obtained from OECD (2013a). An example often cited, is the loss of local employment.

${ }^{4}$ This can also relate to the protection of state-owned national champions. This has also been highlighted in a recent "Pulse" survey of CEOs conducted by Price Waterhouse Coopers (PwC, 2015a), 54\% said that protectionist policies have ensured ownership of essential strategic assets remain within national control. In addition, $72 \%$ believe that government ownership helps discourage the entry of foreign competitors - a benefit for domestic private companies in times of economic crisis, but also an obvious barrier to global trade.

${ }^{5}$ Ibid, and PwC (2015b). According to the PwC CEO pulse survey 54\% said that protectionist policies have ensured ownership of essential strategic assets remain within national control.
} 
- SOE governance. This concern can relate to a number of issues, including a lack of separation between ownership and regulation in home country owning the SOE. This calls into question the quality of regulatory and enforcement regimes, and can pose specific problems in cross-border operations because the host country regulators' habitual resource in the case of impropriety is the home country regulators. Other concerns include, political appointments at the level of the board or management, which would de facto put into question the independence of the company's governing bodies; and general concerns regarding obtaining a sufficient level of transparency and disclosure regarding the commercial orientations of an SOE if there are concerns about a weakly incorporated SOE or one which operates close to the public administration of its state owner.

- Corruption risk. SOEs engaging in international business may run a particular risk of becoming embroiled in corruption. A recent report by the OECD taking stock of the convictions against firms and individuals for bribing foreign public officials since 1999 found that SOE officials are among the most active recipients of bribes(OECD, 2014). (Conversely, SOEs are not necessarily more active in offering bribes than private firms.) An estimated 27 per cent of all the bribes in the sample - and 80 per cent of the amounts involved - were received by SOE employees.

- Other concerns. These were identified by survey respondents to include i) lower labour standards; ii) concerns of a cyclical nature (i.e. short investment horizons correlated with political cycles in foreign countries, thus implying volatility in a domestic context); and, iii) concerns related to social and cultural frictions.

The survey asked regulators to identify the main types of concerns that arise when foreign SOEs seek to establish themselves in their jurisdiction; and to evaluate the scale of concern, ranging from "strong", "somewhat" or "less" of a concern; or to establish whether the question was "not applicable" (Figure 1).

"Strong concern." In the order of most to least respondents the following issues were considered of "strong" concern: $1^{\text {st }}$ place) maintaining a level playing field; $2^{\text {nd }}$ place) competition enforcement policies; $3^{\text {rd }}$ place) public interest; and insufficient information about entrants; $4^{\text {th }}$ place) net economic benefits; and corruption risks; and $5^{\text {th }}$ place) protect national champions; and ad hoc political intervention.

"Somewhat concern": In the order of most to least respondents the following issues were considered of "somewhat" concern: $1^{\text {st }}$ place) ad hoc political intervention; and SOE governance; $2^{\text {nd }}$ place) renationalisation of private firms; $3^{\text {rd }}$ place) public interest; net economic benefit; protect national champions; and maintaining a level playing field; $4^{\text {th }}$ place) competition enforcement policies; insufficient and information about entrants; $5^{\text {th }}$ place) corruption risks; $6^{\text {th }}$ place) public interest; and "other".

"Low concern": In the order of most to least respondents the following issues were considered of "low" concern: $1^{\text {st }}$ place) corruption risk; $2^{\text {nd }}$ place) national security; protect national champions; insufficient information about entrants; re-nationalisation of private firms; $3^{\text {rd }}$ place) net economic benefits; and SOE governance; $4^{\text {th }}$ place) public interest; ad hoc political intervention; and competition enforcement policies; and $5^{\text {th }}$ place) maintaining a level playing field. 
Figure 1. Concerns about foreign SOE investment

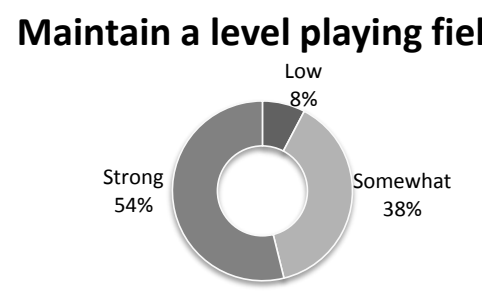

Protect national champions

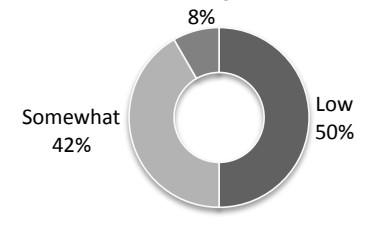

Insufficent information

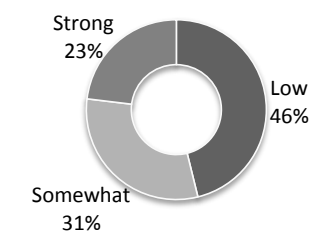

Corruption Risk

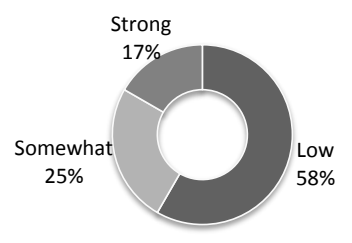

Ad hoc political intervention

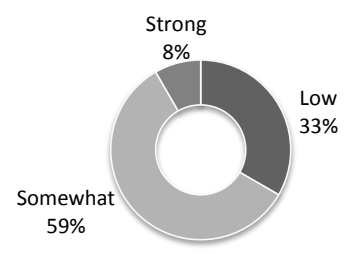

National Security

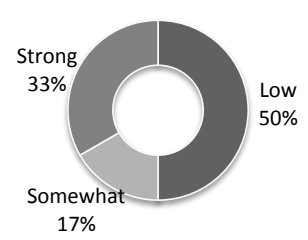

Public Interest

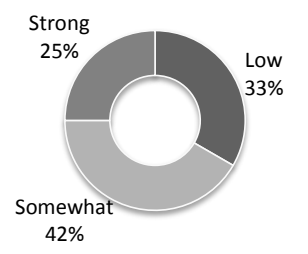

Re-nationalisation

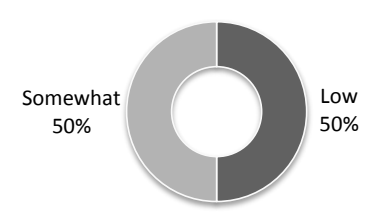

SOE governance

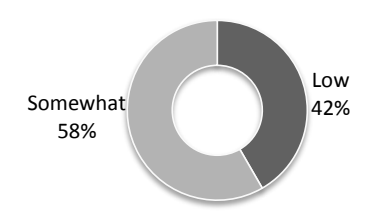

Competition enforcement

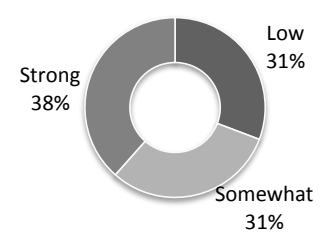

Net economic Benefits

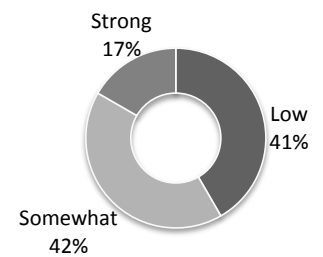




\subsection{Concerns relating to national security}

Over the last decade considerations about the national security ramifications of foreign investment by SOEs have increased in a number of host countries. As mentioned earlier, this relates to the fact that SOEs have become a growing presence in the global marketplace. It also relates to the concentration of SOEs in the network industries and other sectors that an increasing number of countries consider as part of their essential or critical infrastructure. However, a pertinent question that was asked by the survey is whether security concerns arising from SOE cross-border investment differ materially from the case where the foreign entrant is owned by private investors (See also OECD, 2015a for additional analysis)

Over $50 \%$ of respondents consider that the national security threats posed by investment by foreign SOEs are "the same level as privately-owned firms" (Figure 2). Among a third of respondents which identify foreign SOE investment as "somewhat more of a threat" particular concerns were identified as: i) the use of SOEs to achieve foreign policy goals; ii) the operation of SOEs in strategic sectors (i.e. power and gas transmission); iii) the possibility of SOE investment escalating potential conflict at the diplomatic levels; and, iv) intervention by the government owner in company operations, especially in periods of crisis.

Figure 2. Foreign SOEs and National Security Threats

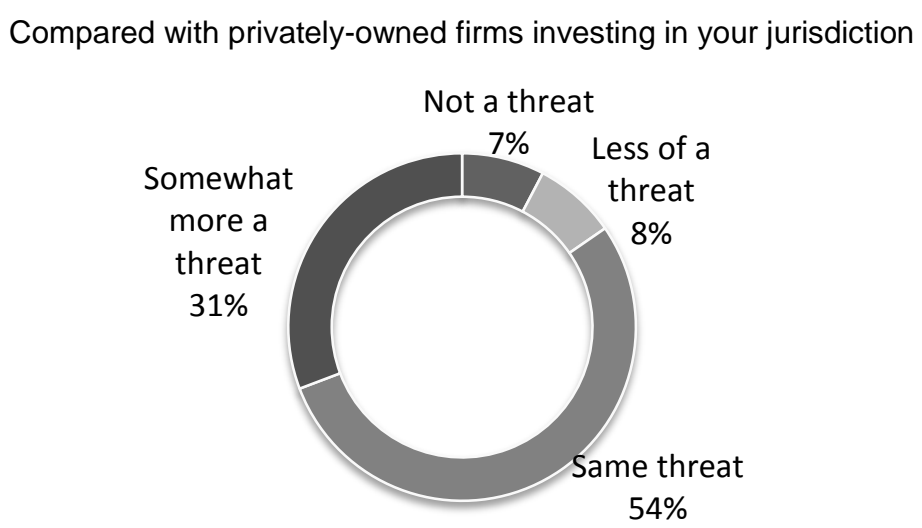

Source: Responses received from the OECD Survey on State-Owned Enterprises in the Global Marketplace (2015)

The survey sought to identify whether foreign SOE ownership of critical infrastructure could pose a direct threat to national security. "Critical infrastructure" can be defined as physical or intangible assets whose destruction or disruption would seriously undermine public safety, social order and the fulfilment of key government responsibilities. According to a 2008 OECD study (OECD, 2008b), critical infrastructure has received special attention in recent changes to national investment policies in some countries. Many countries have national plans or strategies for protecting critical infrastructure, with varying degrees of intervention relating to investment policies. Nevertheless, respondents identified this to be an area of "somewhat concern," with the main concerns focused in relation to the energy (power and gas) and telecom services sectors (Figure 3). Another important factor identified by two respondents was the country of origin of the SOE. Interestingly, some respondents, and additional interviews conducted, suggest that the size of an economy matters (i.e. smaller economies may have to be more open to foreign- 
owned operators; but also more susceptible to risks); for this reason one respondent suggested "institutional settings should be able tackle contingencies."

Figure 3. National security concerns by category

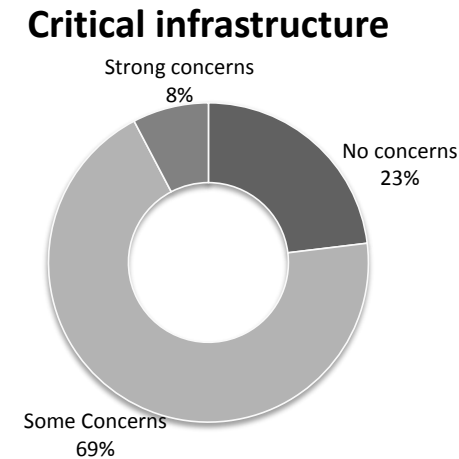

$69 \%$

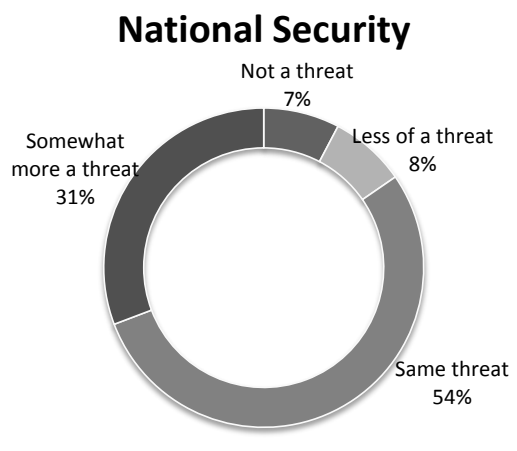

Strategic technology or natural resources

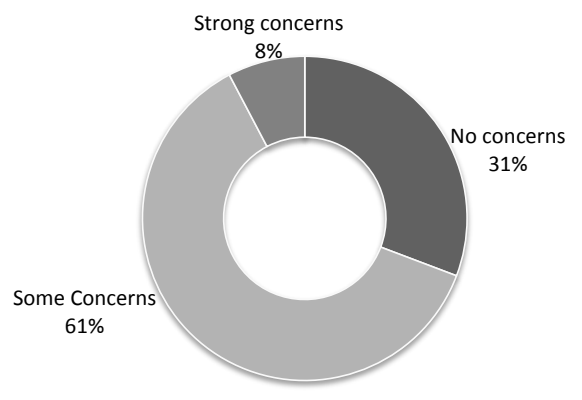

Espionage

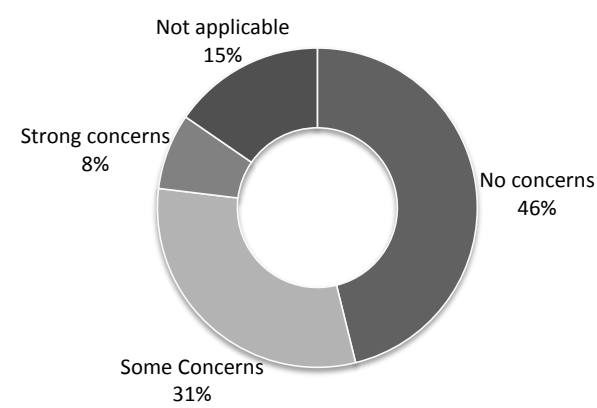

Source: Responses received from the OECD Survey on State-Owned Enterprises in the Global Marketplace (2015)

The survey also gauged policy-makers concerns relating to foreign SOE acquisition of control over strategic technologies or natural resources. Generally, national rules regarding foreign access to technologies directly related to the exercise of armed force and foreign influence- as well as so-called dual use technologies that could serve such purposes - are quite strict. The likelihood that a foreign enterprise would access such technologies or resources, regardless of ownership, usually depends on the degree of strategic cooperation between the home and host countries. In this context, the treatment of SOEs is in most cases unlikely to differ much from privately owned enterprises in like circumstances.

However, foreign SOE acquisition of broader "enabling" technologies and knowledge and access to natural resources of strategic interest, may generate some concerns; and may fall under the category of "national security" depending on the extent to which the technology or national resources in question have strategic implications (examples include energy and inputs to the heavy industries), as is reflected in the fact that over $60 \%$ of respondent's consider this category to be of "some concern" (Figure 3).

Espionage and other illegal information gathering. SOEs subject to direct government interventions could be perceived to have stronger incentives to align themselves with state objectives, and arguably also

\footnotetext{
${ }^{6}$ According to a recent review of investment policies conducted by the OECD "ownership does not appear to have been the driving consideration for national security treatment by host countries to date. Foreignness seems to have been the more important factor, with private as well state-owned investments occasionally subjected to review." OECD, 2015b, and OECD 2015d.
} 
a stronger sense of impunity. The risks could be perceived to include the embedding of intelligence agents as key staff in the foreign-invested enterprise as well as intelligence gathering in the course of its business operations. Almost half ( $46 \%$ ) of the respondents "do not consider this to be a concern". Whereas almost $40 \%$ of combined respondents have "some" or "strong" concerns, but further indicated that such concerns may not be limited to SOEs. One respondent indicated "strong" concern related specifically to SOEs domiciled outside of the OECD and EU areas (Figure 3).

Different treatment of SOEs under investment reviews. Those countries that have overall review mechanisms for incoming FDI could potentially bring these to bear on the investment by a foreign SOE, whether justified by concerns about the general national interest, economic benefits or a more narrowly defined national security criterion. However, over $90 \%$ of respondents indicate that SOEs are not subject to more intensive monitoring (there were zero "yes" answers provided to this question).

This result resonates with a 2015 OECD FOI Survey of Investment Policies Related to National Security (OECD, 2015b) review in which relatively few countries report explicitly treating SOEs and private investors differently for national security reasons; but other rules may also apply. Although government control was found to be a structuring criterion of investment policies related to national security; only three of 17 surveyed countries report explicitly treating foreign SOEs differently from private investors on national security grounds (these were Australia, the Russian Federation and the United States). Canada also has a more restrictive screening process under their "net benefit" tests. Furthermore, seven adherents to the OECD Declaration on International Investment and Multinational Enterprises Australia, Iceland, Israel, Mexico, Spain, Costa Rica and Turkey - have reported special measures restricting such entities' entitlement to either market access or national treatment. In some cases these measures apply generally to SOEs and other government-controlled entities, in other cases they are restricted to specific sectors or activities (e.g. communication, transport or petroleum sectors). (See a recent overview of the relevant rules as provided by OECD $(2015 \mathrm{c})^{7}$

Figure 4. More intensive scrutiny of investment due to national security concerns

Of foreign SOEs or government-controlled enterprises

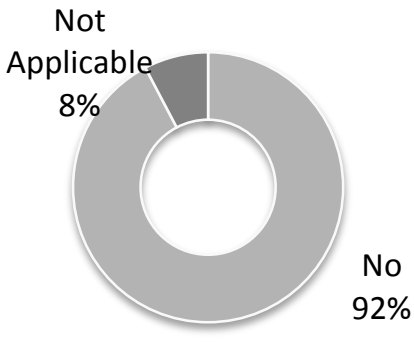

Source: Responses received from the OECD Survey on State-Owned Enterprises in the Global Marketplace (2015)

\footnotetext{
${ }^{7}$ An OECD report states that "Nonetheless this does not preclude that investments by foreign SOEs may receive greater scrutiny than investments by non-state owned enterprises in other countries' screening or review mechanisms. For example, under New Zealand's inward investment review mechanism, "foreign government investors with non-commercial motivations" may be part of the assessment conducted by the authorities of whether the investment proposal meets the 'economic interests' factor to pass the national interest test." [See Freedom of Investment Process: Investment Policies Related to National Security: a Survey (OECD, 2015b, and 2015c)]
} 


\subsection{Competitive situation of SOEs}

The survey further gauged concerns of an economic nature, relating to the competitive position of SOEs in the home market, which could adversely impact competition in the host market. The types of concerns highlighted related to (for more background refer to Capobianco and Christiansen, 2011):

Preferential financing from state banks or other financial institutions. Preferential financing could entail credits received directly from governments, or provided via state-controlled financial institutions, at below market interest rates. One additional concern highlighted by a respondent includes: preferential lending by state-owned financial institutions to private companies for the expansion/maintenance of their production capacities even in a situation where these companies continue to make losses and there is no prospect to gain profits in their businesses due to low profitability in the industry.

Outright subsidies. Some SOEs receive direct subsidies from their government or benefit from other public forms of financial assistance to sustain their commercial operations. For example, the favourable tax regimes or exemptions from certain taxes that are enjoyed by SOEs are tantamount to selective government subsidies. Another form of subsidisation is in kind benefits, for instance where state-owned operators in the network industries receive benefits such as land usage and rights of way at a price significantly below what private competitors would have had to pay in like circumstance. These exemptions artificially lower the SOEse costs and enhance their ability to price more efficiently than competitors subject to a full tax regime.

Privileged position in the domestic market. In many cases, governments entrust SOEs with exclusive or monopoly rights over some of the activities that they are mandated to pursue. This can be seen, for example, in postal services, utilities and other universal services that the state decided to pursue through state-controlled entities. Where SOEs continue to benefit from a legal or natural monopoly this may be of little practical consequence for the competitive landscape, but a number of SOEs in the network industries operate as vertically integrated structures with incipient monopolies in parts of their value chains. This can have a direct effect on relative competitiveness, and it may also allow them to influence the entry conditions of would-be competitors across a number of commercial activities. Moreover, concerns may arise as to preferences towards SOEs in domestic public procurement.

Explicit or implicit guarantees. State guarantees for SOEs, can be of concern if they reduce the cost of borrowing and enhance their competitiveness vis-à-vis their privately-owned rivals. In practice, it can be difficult for the state to convince markets that a given enterprise is not subject to such guarantees.

Regulatory forbearance or exemptions. SOEs of some sectors and/or some corporate forms may enjoy outright exemptions from bankruptcy rules (because equity capital is locked, SOEs can generate losses for a long period of time without fear of going bankrupt). In some cases, SOEs are not subject to the same costly regulatory regimes as private firms, lowering their operating costs. According to the national context, these exemptions may, for example, include compliance with disclosure requirements and exemptions from antitrust enforcement, building permit regulations or from zoning regulations. This concern has also been highlighted by a business survey (PWC CEO Pulse Survey), for which $67 \%$ of surveyed CEOs "felt that government ownership influences regulation and enforcement in industry".

Preferential access to state information. SOEs may also benefit from information asymmetries. Information asymmetries occur when SOEs have access to data and information which are not available to their private competitors or only available to a limited extent. 
Other. Two concerns were cited: i) One concern is excess capacity: This concern relates to advantages accrued from government supports in order to expand/maintain production capacity even in a situation where SOEs continue to make losses and there is no prospect to gain profits in their businesses due to low profitability of the industry; ii) a second concern relates to regulatory compliance by the foreign $\mathrm{SOE}$ in the host jurisdiction.

Figure 5. Concerns about the competitive situation of SOEs

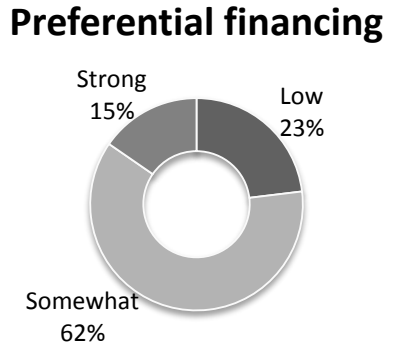

Outright subsidies

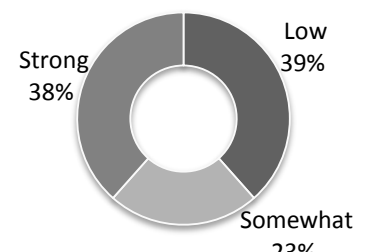

$23 \%$

Position in domestic marketplace

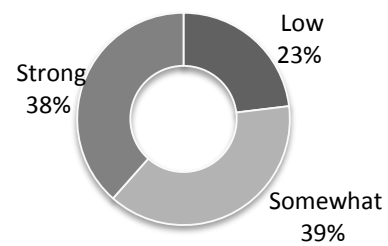

Explicit/Implicit guarantees

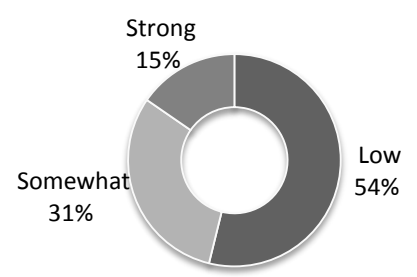

Regulatory forbearance/exemptions

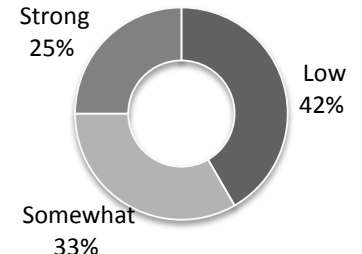

Access to state information

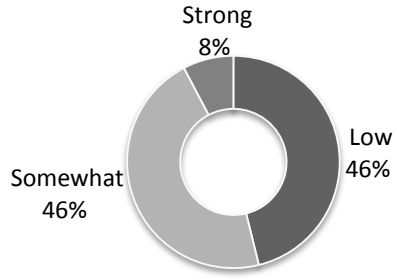

Source: OECD Survey on State-Owned Enterprises in the Global Marketplace (2015)

The survey asked regulators to identify the main types of concerns about the competitive situation of SOEs in their home market; and to evaluate the scale of concern, ranging from "strong", "somewhat" or "less" of a concern; or to establish whether the question was "not applicable".

"Strong concern." In the order of most to least respondents the following issues were considered of "strong" concern: $1^{\text {st }}$ place) outright subsidies; and privileged position in the marketplace; $2^{\text {nd }}$ place) regulatory forbearance or exemptions; $3^{\text {rd }}$ place) preferential financing from state banks or other financial institutions; explicit implicit guarantees; preferential access to state information; and other types of information.

Somewhat concern": In the order of most to least respondents the following issues were considered of "somewhat" concern: $1^{\text {st }}$ place) preferential financing from state banks or other financial institutions; $2^{\text {nd }}$ place) privileged position in the domestic market; and preferential access to state information; $3^{\text {rd }}$ place) explicit or implicit guarantees; and regulatory forbearance or exemptions; and $4^{\text {th }}$ place) outright subsidies. 
"Low concern": In the order of most to least respondents the following issues were considered of "low" concern: $1^{\text {st }}$ place) explicit or implicit guarantees; $2^{\text {nd }}$ place) preferential access to state information; $3^{\text {rd }}$ place) outright subsidies; regulatory forbearance or exemptions; and, $4^{\text {th }}$ place) preferential financing from state banks or other financial institutions; and privileged position in the domestic market.

Does ownership matter? When asked whether unfair competitive advantages are due to public ownership, almost all respondents do not consider public ownership to be a key determinant of competitive advantages (Figure 6).

Figure 6. Unfair competitive advantages due to public ownership

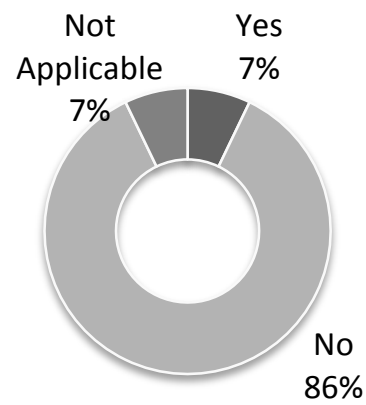

Source: Responses received from the OECD Survey on State-Owned Enterprises in the Global Marketplace (2015)

This finding contrasts with perceptions from the business community. An earlier cited PwC "Pulse" survey $(\mathrm{PwC}, 2015)$ found that 83 per cent of surveyed CEOs had "concerns that government ownership distorts competition to some degree." The results emanating from the 2014 "OECD Business Survey on State Influence on Competition in International Markets" (OECD, 2014) further corroborates this view, the authors note that: "Ownership status of firms is perceived to matter; the reported severity of the impact of preferential treatment of enterprises by governments is higher for state-owned enterprises." Moreover, businesses perceived that the same advantages are not afforded by governments in their home markets but by foreign governments (Figure 7). (OECD, 2015d)

Figure 7. Preferential treatment of competitors by foreign governments

A business perspective

by own government

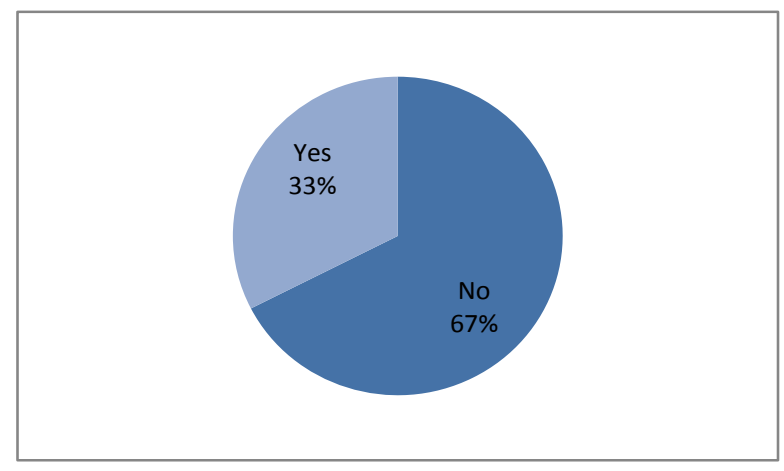

by foreign governments

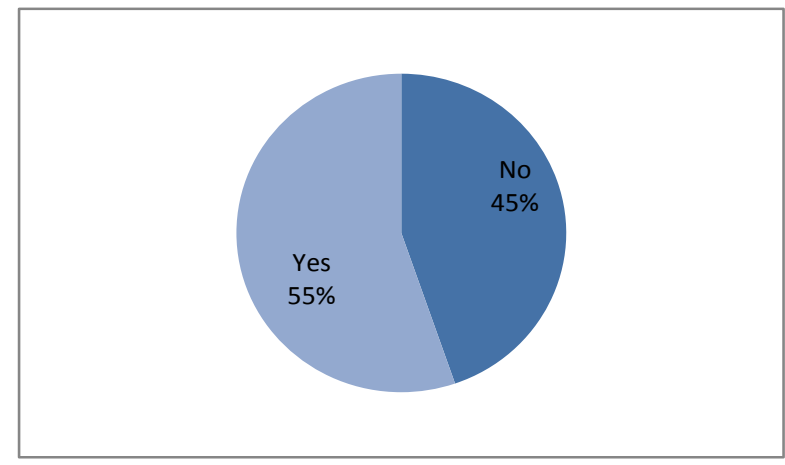

Source: Responses received from the OECD Business Survey on State Influence on Competition in International Markets 
Competition concerns. With regarding to competition concerns, specifically relating to anticompetitive mergers, cartels, monopolisation or abuses of dominance, over $90 \%$ of jurisdictions report that they do not have specific concerns vis-à-vis foreign SOE operations in their jurisdictions. This finding is largely consistent with the "ownership" neutral approach of competition policy in most jurisdictions and the fact that most SOEs are not subject to foreign sovereign immunity in their commercial operations. It can also be reflected in fact that most SOEs, across jurisdictions, are now widely subject to competition law (although as cited competition enforcement can still be a challenge). See OECD, 2015d and OECD, 2012.

Acquisition premiums. Most reporting jurisdictions are not concerned by the ability of SOEs to pay higher or lower acquisition premiums that a private company in like circumstances. Only two jurisdictions indicate concerns that foreign SOEs may pay less than normal market value because of undue benefits in the home jurisdiction (relating to privileged financing, guarantees or subsidies). The potential concerns are cited as: i) excessive production capacity of certain sectors especially material industries support by public measures; and ii) unfair price competition due to preferential financial support in the home country (although this concern can apply equally to SOEs and other companies) (Figure 8). ${ }^{8}$

Figure 8. Acquisition premiums

As compared with private competitors

Higher acquisition premiums

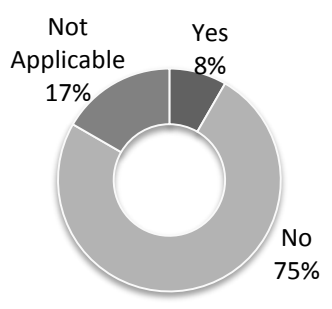

Lower acquisition premiums

Not Applicable Yes

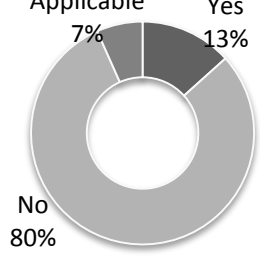

Source: Responses received from the OECD Survey on State-Owned Enterprises in the Global Marketplace (2015)

\subsection{Legal, regulatory and enforcement issues}

When companies operate in multiple jurisdictions, the challenge to enforce the relevant laws and regulations inevitably becomes more complicated. This happens regardless of ownership, but the case of SOEs may be (or being perceived as such by host country authorities) particularly complicated, especially if related to foreign sovereign immunity ${ }^{9}$. That said only one jurisdiction reports concerns with regard to SOEs shielded from law enforcement through the invocation of sovereign immunity; with the caveat that the risk was identified to be small and limited to the non-commercial activities of the SOE. This would support the survey's findings that policy-makers are not particularly concerned with regard the application

\footnotetext{
${ }^{8}$ These results are further corroborated by the empirical analysis in the OECD, 2015d, which purports that fully stateowned enterprises "do not pay higher premiums in their acquisitions, and although their payment modalities appear to reflect lower financial constraints."

${ }^{9}$ Under the doctrine of foreign state immunity, one state is not subject to the full force of rules applicable in another state. In theory this implies that if weakly operated SOEs (sometimes referred to as quasi-corporations) that essentially operate as part of the general government sector are active abroad, they can be shielded from legal enforcement. That said, as noted by Gaukrodger (2010), as States have become more involved in commercial activities, many jurisdictions now apply a more "restrictive" theory of immunity at least in cases brought by private parties.
} 
of laws/regulations; authority and jurisdiction; investigation powers; sanctions and remedies vis-a-vis SOEs and as compared with privately-owned enterprises.

Access to information. Although "insufficient information about entrants" was identified as "somewhat" or a "strong" concern by almost $40 \%$ of responding jurisdictions (see section 2.1 ), half of the respondents report that that they are able to obtain sufficient information about foreign SOEs operating in their markets. The majority of respondents rely on voluntary disclosure by SOEs or their government owners; cross-jurisdictional co-operation; or a combination of the two to access information regarding foreign SOE entrants. As one respondent pointed out, co-operation can be sought through regional/international competition networks; and existing agreements between states. Additional information is sought in mandatory disclosures by SOEs (as mandated by law); and declarations for statistical purposes in foreign investment registries; further highlighting the importance of raising and harmonising transparency and disclosure practices by SOEs.

Figure 9. Obtaining information about foreign SOEs

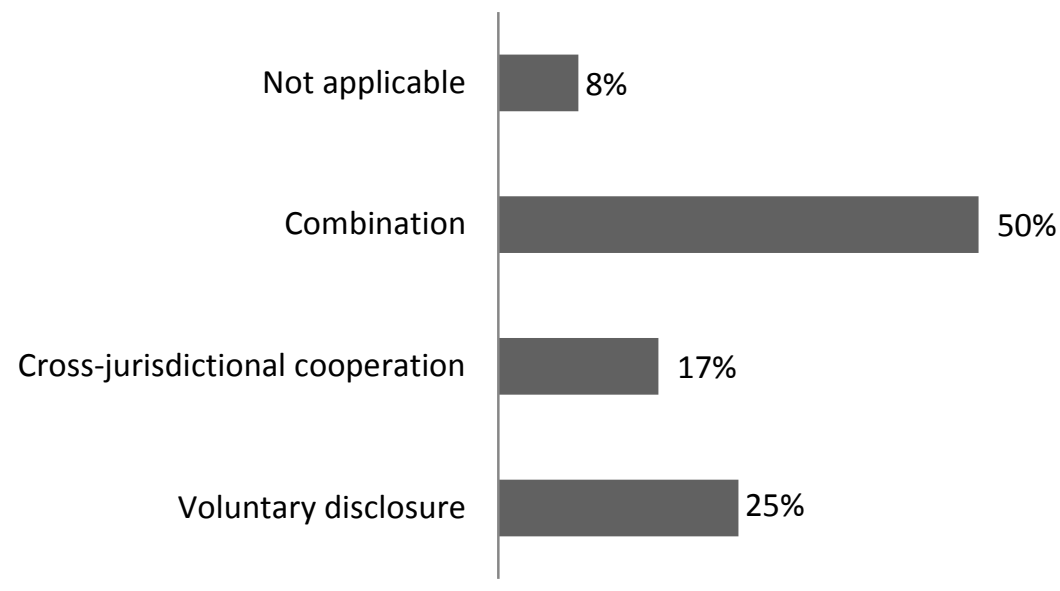

Source: Responses received from the OECD Survey on State-Owned Enterprises in the Global Marketplace (2015)

\subsection{Transparency and governance of state-owned enterprises}

As highlighted under section 2.1, "concerns regarding the governance of SOEs" was an area that 40 percent of respondents considered as "somewhat" of a concern. This part of the survey delves deeper into those considerations, examining a) what aspects of an SOE's governance structure might give rise to concern; and b) whether and what types of information on the transparency and governance of an SOE can sway a decision to allow a foreign SOE to invest or operate in a jurisdiction.

Given most respondents are adherents to the OECD Guidelines on Corporate Governance of StateOwned Enterprises (OECD, 2015e), it is not surprising, that many aspects of SOE governance may be highlighted of concern depending on the extent to which the Recommendations are followed. These aspects can include (Figure 10):

- Independence of corporate structures and of the board. If the state intervenes frequently and/or on an ad-hoc basis in the managerial and board functions of SOEs then those SOEs effectively become agents of the state rather than autonomous corporate entities. It has further been highlighted to be factor weighing in on merger analysis by competition authorities (both in identifying the notification threshold and in the substantive analysis). (SeeOECD, 2015d.) 
- Political interference in decision-making. This issue relates to whether the state grants SOEs sufficient day-to-day autonomy to ensure foreign regulators that they act in pursuit of commercial rather than political objectives.

- Quality of financial and non-financial information. A lack of information about the objectives and operations of a foreign SOE can be a cause of concern, where regulators may have particular concerns about the commercial orientation of a company. Quality information would consist of financial reporting, and non-financial reporting such as disclosures of ultimate beneficiary ownership and control, corporate organisation, commercial and non-commercial priorities, and, relationship with stakeholders and related parties.

- Risks of being implicated in cases involving foreign corrupt practices. As highlighted under section 2.1, SOEs engaging in international business may run a particular risk of becoming embroiled in corruption. Information regarding any pending cases or any judgements may quell any doubts regarding a particular SOE's track record; but also demonstrate a certain level of transparency and disclosure which may be a factor that can sway the decision of a regulator.

Figure 10. Concerns about SOE governance

Aspects that may influence the decision to allow a foreign SOE to operate in your jurisdiction

\section{Corporate Independence}

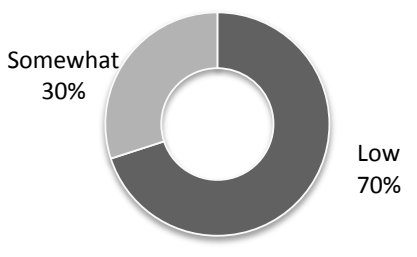

Independent board members

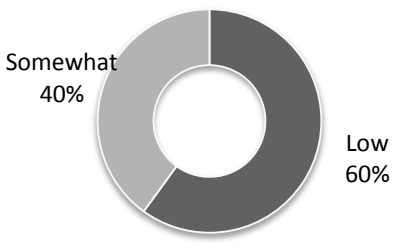

\section{Political interference}

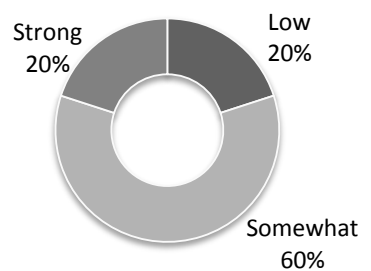

Quality of information

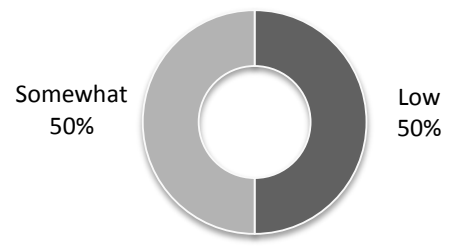

\section{Risks of foreign corrupt practices}

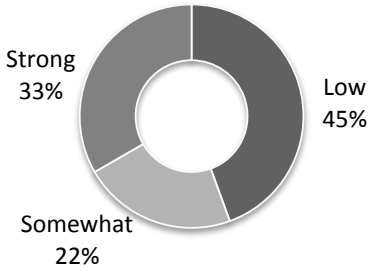


Some respondents considered that the questions were "not applicable" to the extent that identical requirements are asked of all foreign legal entities, regardless of ownership. For those jurisdictions that considered some issues could be of concern, the following areas (listed in order of ranking) were identified. Some respondents only attributed those concerns to foreign SOE investment in specific sectors (i.e. power transmission):

- Company-specific objectives ( $1^{\text {st }}$ place). SOE are often charged "public policy objectives" -which often relate to the provision of public services, or to remedy a market imperfection. In emerging economies, SOEs are sometimes charged with carrying out elements of national development strategies and/or the conduct of industrial policy. In the case of cross-border operations of SOEs the question arises whether public policy objectives (or any compensation provided for them) are carried into foreign jurisdictions. Without proper transparency and disclosure, concerns may arise from a lack of understanding about the objectives and operations of the foreign SOE in the host market. ${ }^{10}$

- Ownership structures $\left(2^{\text {nd }}\right.$ place). This point relates to SOE management and related governance structures and their ability to exercise duties independently and autonomously from the State. Otherwise, a potential area of concern may be that SOEs are subject to ad-hoc political interventions and sudden changes of direction that could imperil the credibility of the company's stated objectives. ${ }^{11}$

- State-ownership policy ( $2^{\text {nd }}$ place). The disclosure of objectives underpinning SOE operations in general, if disclosed, can serve to alleviate any potential concerns regarding the intentions of a particular foreign SOE's investment. The OECD SOE Guidelines state that "the policy should inter alia define the overall rationales for state ownership, the state's role in the governance of SOEs, how the state will implement its ownership policy and the responsibilities of those government offices involved in its implementation."

- Annual reports ( $2^{\text {nd }}$ place). The availability of annual reports (preferably externally audited), is an important element of information that can assist regulators and policy makers. The annual report should, at minimum, adhere to standards practiced in the private sector. However, additional information may be warranted if the SOE benefits from state- support; disclosure could include details on any state grant or subsidy received by an SOE, any guarantee granted by the state to the SOE for its operations, as well as any commitment that the state undertakes on behalf of an SOE.

- Corporate governing bodies $\left(3^{\text {rd }}\right.$ place). If the state intervenes frequently and/or on an ad-hoc basis in the managerial and board functions of SOEs then those SOEs effectively become agents of the state rather than autonomous corporate entities. This can be a concern from the perspective of regulators in the host country because it implies that, through the SOE, a foreign sovereign power is acting in their marketplace. It can further complicate matters under a merger review.

- $\quad$ Other $\left(4^{\text {th }}\right.$ place $)$. Not specified.

${ }^{10}$ For this reason the OECD SOE Guidelines (OECD, 2015e) recommend that government ownership of SOEs establish a degree of clarity around the objectives - economic and otherwise - that a given state-owned enterprise is instructed by its owners to pursue. If these objectives are not clear for the government owner, it may exacerbate concerns perceived by the host country.

${ }^{11}$ For SOEs, especially whether the State may be full or majority owner, it is clear that the State will exercise some influence on the SOE with regard to its corporate strategy and potentially with regard to any public policy objectives it carries out, but this should be done through the proper channels, as would any major shareholder of a privately-owned enterprise. 


\section{Concerns of SOEs (and their owners) when operating abroad}

This part of the Working Paper focusses on survey results relating to concerns of SOEs and their owners when operating abroad. It was mainly answered by government authorities responsible for the oversight of state-owned enterprises with international operations. The first section focuses on concerns and challenges that SOEs (and their owners) perceive when operating abroad, these can be general challenges or those specific to their public ownership status (section 3.1). The second section aims to gauge the impact certain factors may have in decisions by SOEs (and their owners) to internationalise (section 3.2). It should be noted that all but one of the respondents to this section OECD member countries and are therefore adherents to the OECD SOE Guidelines. Therefore, it can assume that - although country practices may vary - SOEs from these countries (and their government owners) aspire to follow to the instruments recommendations. ${ }^{12}$

\subsection{Impediments to trade and investment by SOEs}

Multinational enterprises may face varying degrees of challenges when operating abroad; these challenges may be related to the status of the company itself (reputation, governance, nationality, market power, etc.); but challenges may also be related to the investment climate in a particular jurisdiction. These challenges can include, but not limited to: the level of ease of doing business; quality, cost and level of administrative/regulatory procedures and burdens; the overall governance environment; and the level of competition. These challenges are often not unique to the situation of an SOE seeking to internationalise and may well reflect those impediments faced by privately-owned companies. Certain challenges may be accentuated or "SOE specific" including those identified by some respondents to be: i) treatment in investment review processes; ii) restrictions imposed by investment or trade agreements; and, iii) treatment under competition laws and policies. These challenges can be identified and described as follows:

- Treatment in administrative review processes. Cumbersome or lengthy investment review/screening process. As explained in section 2, this may arise if there are particular or additional procedures in place to screen/review SOE investments. As highlighted, few countries have explicit provisions related to SOEs in their investment policies.

- Restrictions imposed by investment or trade agreements. Specific provisions relating to stateowned enterprises are increasingly being made reference to in investment or trade agreements. These agreements may set out mutual commitments and expectations for the conduct of SOE. ${ }^{13}$

- Ability to trade with subsidiaries subsequent to entry. Restrictions on transactions due to cumulative or combined market share among entities owned by the same parent/holding company, or government agency, which can be viewed as impeding competition. This can be linked to considerations as to whether SOEs can be considered as a "single entity".

- Treatment in administrative and regulatory processes. Acquiring licences, permits, or visas; conforming to environmental standards or industry specifications. Some jurisdictions may place closer attention to foreign companies and especially foreign SOEs on regulatory compliance. ${ }^{14}$

\footnotetext{
${ }^{12}$ Lithuania as accession candidate to the OECD is currently undergoing a review against the OECD SOE Guidelines.

${ }^{13}$ Ongoing negotiations of international trade and investment treaties have grappled with the role of SOEs, and one of the topics for discussion has reportedly been whether it would make sense to aim for broad "competitive neutrality" commitments.

${ }^{14}$ OECD, 2015dfound that, "Although there are common perceptions that foreign state-owned companies might abide to different (possibly lower) standards of responsible business conduct (RBC), (including environmental
} 
- Specific industry restrictions, such as thresholds and limits on foreign ownership. SOE are often concentrated in sensitive sectors which may be subject to specific industry restrictions and limits on foreign ownership. As such, the barriers to entry may not be particular to the ownership status of the company, but related to the line of business it conducts.

- Treatment in procurement processes. Restrictions may be in place that may hinder foreign or foreign SOE participation (i.e. local content requirements, history of previous contracts, requirements for technology transfer).

- Treatment under competition laws and policies. In the absence of anti-competitive conduct, there is little scope for challenges to arise under cartel or anti-monopoly reviews. However, increased scrutiny of a SOE's status may arise. However, there could also be a perceived concern on the part of the foreign SOE entrant, that competition laws and policies or the overall regulatory regime is more favourable to the local incumbent (SOE or other).

- Institutional factors. Working with local governments, local communities, or trade unions could be a source of concern; these barriers may also relate to the general reputational issues or distrust (see below two points).

- Negative media coverage. General reputational issues; more heightened public attention; scepticism about trade or investment. ${ }^{15}$

- Ideological, cultural or language barriers. Overcoming distrust and general reputational issues. Disadvantages due to cultural differences or language barriers. SOEs from one country may attract more distrust from those of other countries. (Ding, 2014)

The survey asked SOEs (and their owners) to identify the main types of concerns they face when operating abroad; and to evaluate the scale of concern, ranging from "strong", "somewhat" or "less" of a concern. The results are as follows (Figure 11):

- "Strong concern." In the order of most to least respondents the following issues were considered of "strong" concern: $1^{\text {st }}$ place) treatment in administrative and regulatory processes; $2^{\text {nd }}$ place) treatment in procurement processes; $3^{\text {rd }}$ place) ability transact with subsidiaries subsequent to entry; specific industry restrictions; $4^{\text {th }}$ place) restrictions imposed by investment or trade agreements; treatment under competition laws and policies; $5^{\text {th }}$ place) treatment in investment review process; institutional factors; negative media coverage; ideological, cultural or language barriers.

and labour standards) in their home market - and that unless the host economy has strong capacity for enforcing higher RBC standards across all firms in its jurisdiction, this behaviour may further be exacerbated when the firms operate overseas. There is little evidence that state-owned companies operating abroad differ substantially in their RBC behaviour from equivalent private-owned companies originating in the same economy, and operating in the same destination market. In some cases SOEs may actually be held to higher standards than equivalent private firms, because of the reputational risk otherwise incurred by the home government."

15 For example, a 2013 public opinion poll conducted in Canada found that 52 per cent of Canadians oppose investment from SOEs, with 23 per cent strongly against such investment. (Woo, 2014). The 2014 Lowy poll, found that $60 \%$ of Australians remained opposed to foreign investment in Australian agriculture, with particular opposition to Chinese investment. It is not clear whether this public sentiment is directed specifically at SOEs, or just at Chinese investors in general. Although they are inter-linked. 
Figure 11. Concerns of SOEs and their government owners

Related to operations abroad

Investment Review

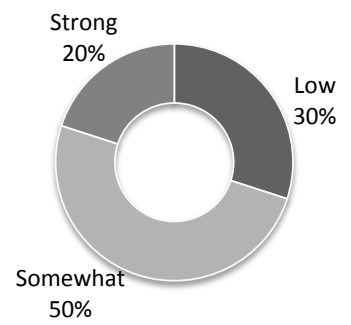

Trade/investment agreements

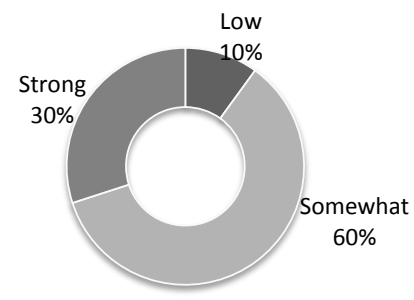

Transactions with subsidiaries

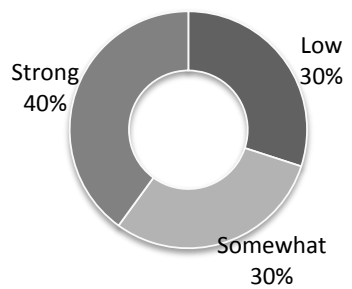

Admin. \& regulatory procedures

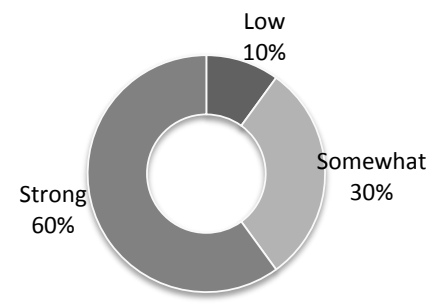

Industry restrictions

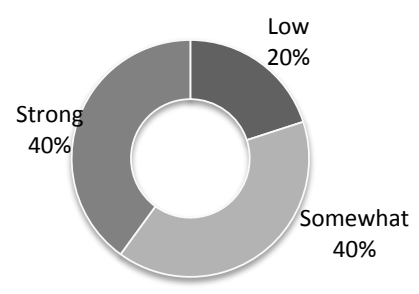

Public procurement

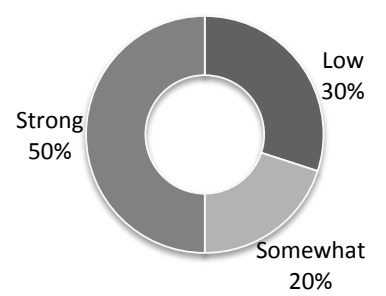

Competition law \& policies

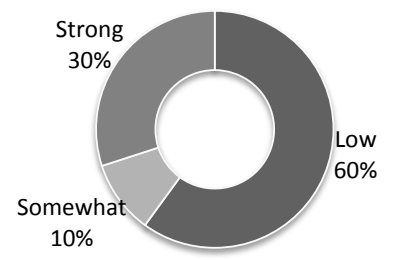

\section{Institutional factors}

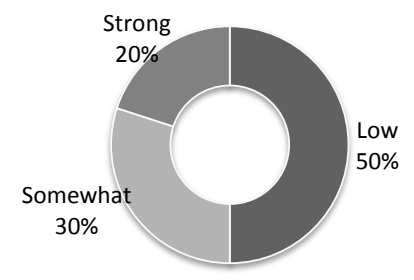

Negative media coverage

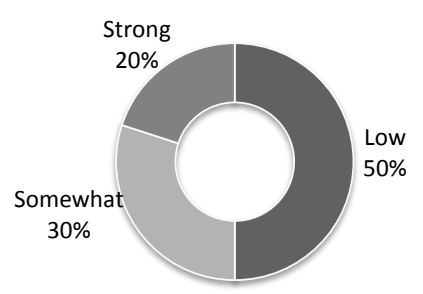

Ideological/cultural/language barriers

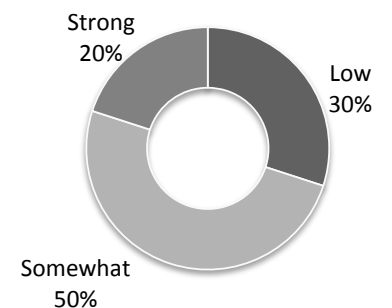


- "Somewhat concern." In the order of most to least respondents the following issues were considered of "somewhat" concern: $1^{\text {st }}$ place) restrictions imposed by investment or trade agreements; $2^{\text {nd }}$ place) treatment in investment review process; ideological, cultural or language barriers; $3^{\text {rd }}$ place) specific industry restrictions; $4^{\text {th }}$ place) ability transact with subsidiaries subsequent to entry; treatment in administrative and regulatory processes; institutional factors; negative media coverage; $5^{\text {th }}$ place) treatment in procurement process; $6^{\text {th }}$ place) treatment under competition laws and policies.

- "Low concern." In the order of most to least respondents the following issues were considered of "low" concern: $1^{\text {st }}$ place) treatment under competition laws and policies; $2^{\text {nd }}$ place) institutional factors; negative media coverage; $3^{\text {rd }}$ place) treatment in investment review process; ability transact with subsidiaries subsequent to entry; treatment in procurement process; ideological, cultural or language barriers; $4^{\text {th }}$ place) specific industry restrictions; $5^{\text {th }}$ place) restrictions imposed by investment or trade agreements; treatment in administrative and regulatory processes.

Main perceived concerns of the foreign jurisdiction. Respondents were further asked to identify - if they perceive that foreign jurisdictions have particular concerns with regard to the objectives of their SOEs' business transaction - what the causes of such concern might be attributed to. The causes are listed below in the order they were attributed by respondents:

- Political unease about the motivations under pinning the actions of the government as a shareholder $\left(1^{\text {st }}\right.$ place $)$

- Perceptions by privately-owned companies in the host country that the SOE has a competitive advantage; and, ( $2^{\text {nd }}$ place)

- Worries by labour groups that foreign SOE can threaten domestic jobs. ( $3^{\text {rd }}$ place);

- General reputational issues with investment from a jurisdiction; or from foreign governments more generally $\left(4^{\text {th }}\right.$ place $)$; and,

- General concerns about SOE efficiency $\left(5^{\text {th }}\right.$ place $)$.

Here, the distinction between public concerns and central government concerns must be carefully kept in mind when identifying and assessing prevalent perceptions of SOE investment across jurisdictions. Moreover, many of the perceptions may not be directly related to government ownership, but to foreign ownership of firms, which relates to the broader "liability of foreignness." 16

Providing access to information on governance arrangements, transparency and disclosure. SOEs and their government owners were further asked whether it helps to provide access to information and disclosure on the company governance and operations, to positively influence host countries regarding the trade and/or investment objectives (an explanation of the importance of these aspects is covered in detail under section 2.5]. The following areas were identified as "very" or "somewhat" helpful and are consistent with those issues of importance highlighted by investment regulators covered under section 2.5 (Figure 12):

${ }^{16}$ Although, the "liability of foreignness" can be accentuated in the case of SOEs; (Eden and Miller, 2004) for example, a survey of Chinese SOE investment in Canada has found that SOEs, as "inexperienced latecomers" have made reputationally costly mistakes - for example failing to apply market principles in strategic or operational decisions - which as undermined perceptions of trust or transparency. (Dobson, W., 2014) 
- "Very helpful." Information related to commercial objectives; and transparency and disclosure practices (financial and non-financial disclosure).

- "Somewhat helpful." Information related to ownership mechanisms, including the ownership entity; governance structures (board composition, board appointees); ownership policy (overall and company specific objectives). Secondarily, commercial objectives and transparency and disclosure practices were considered to be somewhat helpful.

Figure 12. Information disclosure by SOEs

Issues for which information disclosure can positively influence perspectives on SOE transactions abroad

\section{Commercial objectives}

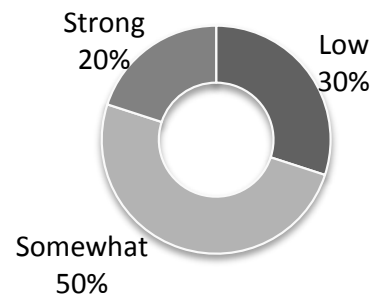

\section{Governance structures}

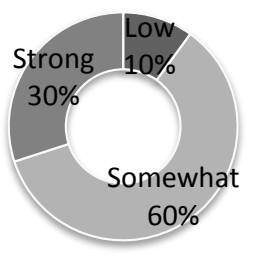

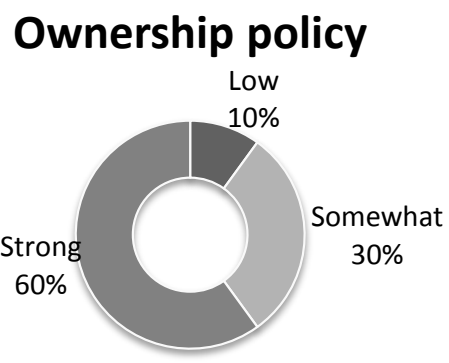

Transparency and disclosure

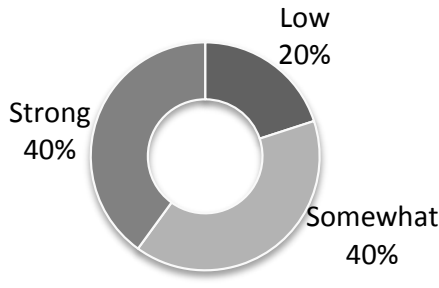

\section{Ownership mechanisms}

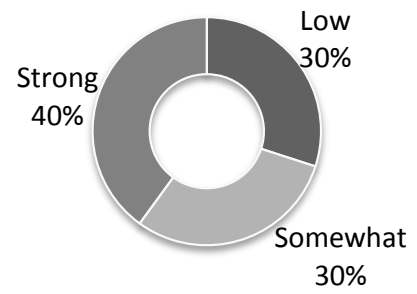

Source: Responses received from the OECD Survey on State-Owned Enterprises in the Global Marketplace (2015)

Accessibility to dispute mechanisms in international trade and investment treaties. All reporting SOEs and their government owners indicate that dispute settlement mechanisms of international trade and investment treaties that their jurisdiction is party to are fully applicable to the case of SOEs; and that those treaties do not foresee a distinct regime for state-owned enterprises. Respondents further note that there have been no instances where cases have been disqualified from such mechanisms and dealt with on a state-to-state basis (rather than an investor-to-state basis), due to the public ownership status of the company in question. 


\subsection{Benefits of cross-border trade and investments by SOEs}

The overseas investment of SOEs (and other enterprises) may be motivated by a range of reasons. The survey asked SOEs (and their owners) to identify the main goals behind cross-border trade and investment by SOEs; and to evaluate the rate of relevancy, ranging from "strong", "somewhat" or "less" relevant. The response can be summarised as follows (Figure 13):

- "Strong relevance." In the order of most to least respondents the following issues were considered of "strong" relevance: $1^{\text {st }}$ place) profit motivation; internationalisation strategy (ability to compete internationally); $2^{\text {nd }}$ place) commercial/industry-specific factors; acquiring/projecting technologies; $3^{\text {rd }}$ place) building up business reputation; building partners at home for markets abroad; $4^{\text {th }}$ place) building brand name; $5^{\text {th }}$ place) secure access to resources; favourable business environment/industry support in other jurisdictions; and $6^{\text {th }}$ place) acquire international management/ know-how.

- "Somewhat relevant". In the order of most to least respondents the following issues were considered "somewhat" relevant: $1^{\text {st }}$ place) commercial, industry-specific factors; acquire international management/know-how; $2^{\text {nd }}$ place) secure access to resources; building brand name; $3^{\text {rd }}$ place) profit motivation; opportunist investment motivated by post-crisis environment; building up business reputation; favourable business environment /industry support in other jurisdictions; $4^{\text {th }}$ place) internationalisation strategy (ability to compete internationally); acquiring/projecting technologies; and building partnership at home for markets abroad.

- "Less relevant". In the order of most to least respondents the following issues were considered "less" relevant: $1^{\text {st }}$ place) opportunistic investment motivated by post-crisis environment; $2^{\text {nd }}$ place) favourable business environment/industry support in other jurisdictions; $3^{\text {rd }}$ place) secure access to resources; $4^{\text {th }}$ place) acquire international management/know-how; acquiring/projecting technologies; building up business reputation; building brand name; and building partnership at home for markets abroad; $5^{\text {th }}$ place) internationalisation strategy (ability to compete internationally).

Among the multiple factors that influence the commercial and strategic motivations behind SOE transactions, profit motivation and ability to compete internationally were cited as most relevant factors to internationalisation. The least relevant factor was cited to be opportunistic investment motivated by a postcrisis environment. ${ }^{17}$

\footnotetext{
${ }^{17}$ Contrasted with international M\&A statistics, which show a peak in SOE M\&A activity from 2007 onwards, the empirical evidence may paint a different picture. Although the data sample largely reflect behaviour by SOEs from emerging markets (with China dominating the numbers). Refer to analysis in OECD, 2015d.
} 
Figure 13. SOE internationalisation - Motivating factors Reported by SOEs and their government owners

\section{Profit motivation}

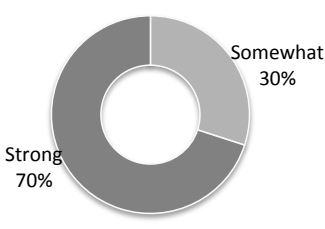

Internationalisation strategy

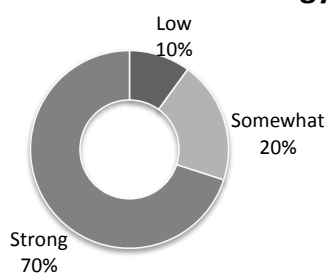

Post-crisis opportunities

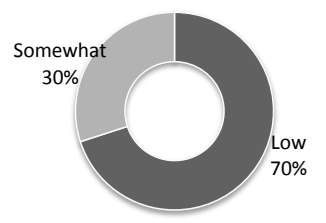

Industry-specific factors

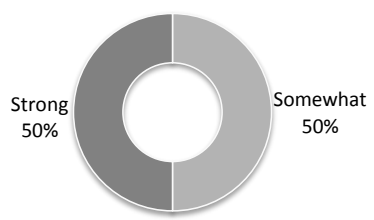

Access to resources

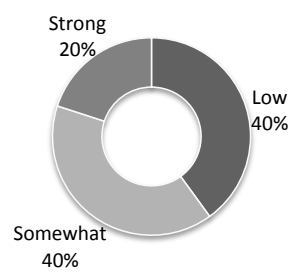

Acquire mngt skills/know how

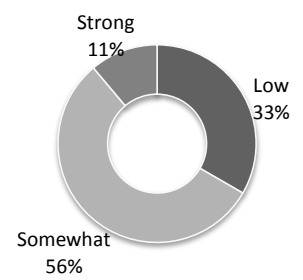

Acquire technologies

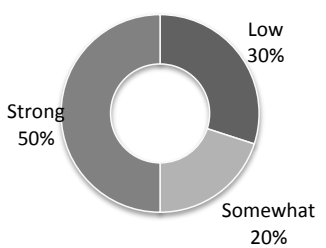

Build reputation

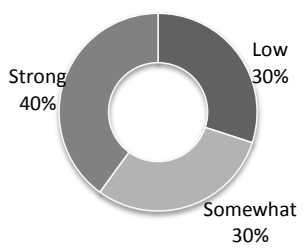

Build brand name

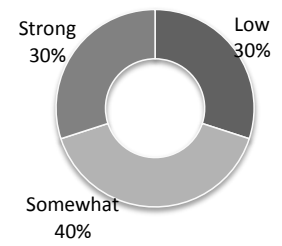

Business env. or supports

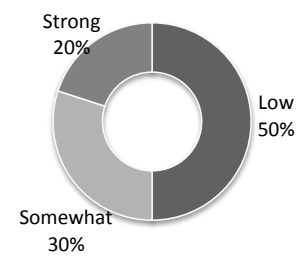

Building partnerships

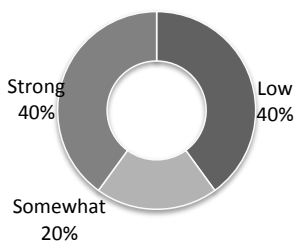

Source: Responses received from the OECD Survey on State-Owned Enterprises in the Global Marketplace (2015) 
These views mainly represent those of SOEs owned by governments from OECD economies, given the sample of respondent jurisdictions; although other surveys of emerging market economies would seem to support these results. ${ }^{18}$

Perceived benefits of trade and investment by SOEs for the recipient country. Survey respondents were further asked to list the perceived benefits of trade and investment by SOEs for the recipient country. These types of can include investment in creation of new productive facilities in the host country that can generate additional employment and development. Among those that were considered to be of "some" or "strong" benefit to the recipient country, the most responses were cited under i) the allocation of capital; ii) in the creation of employment; iii) in the development of new industries; and, iv) in the provision of infrastructure or other basic services; and v) in developing value chains in the host country. The category that was considered of least importance was "rescuing ailing industries.

Responsible business conduct. For what concerns responsible business conduct the survey results indicate that most responding jurisdictions consider responsible business conduct to be a factor that can facilitate international investment by SOEs; and have indicated existing measures intended to enhance responsible business conduct in SOEs active abroad. These measures were reported to include: i) specific requirements on health, safety, security and sustainable business practices; ii) raising awareness through the sharing of best practices in international fora; iii) encouraging the use of codes of ethics and anticorruption compliance policies; and, iv) operating on a level playing field as private companies.

\footnotetext{
${ }^{18}$ These results can be compared with two other studies examining the Chinese SOE experience, specifically. One is a 2014 OECD survey refer to analysis in OECD, 2015d. This survey identified main motivations for overseas expansions of their state-owned enterprises was: better allocating resources globally; acquiring advanced technologies and management experience; and integrating the company's product line and catering for the Chinese domestic market. They claim to have no explicit financial targets, to access financing mostly through internal resources, and to have little involvement from their headquarters in dayto-day operations (OECD, 2014). Likewise a 2014 survey of Chinese SOEs, commissioned from KPMG by the Business Council of Australia, highlights seven motivating factors for SOEs in Australia: global profit seeking; consumer market reach; following Chinese migrants; local integration (notably for subsidiaries in the banking sector); strategic expansion; enabling tourism growth; and brand acquisition (KPMG, 2014).
} 


\section{Concerns related to international trade of goods and services involving SOEs}

This section of the Working Paper addresses results of the survey relating to concerns regarding international trade of goods and services involving SOEs and their cross-border exports or imports; or their provision of goods and services through commercial presence abroad. Parts of this section may overlap with issues covered by section 2 (i.e. FDI-related restrictions to services trade); however, this part of the report tries to hones in on particular concerns for the trade community and was addressed mainly to authorities responsible for trade regulation. The section covers concerns related to the competition with foreign SOEs in international trade (section 4.1) and concerns about the discrimination of domestic SOEs when engaging in international trade (section 4.2); it also draws from results emanating from the 2014 OECD “Business Survey on State Influence on Competition in International Markets.”(OECD, 2015f).

\subsection{Competition with foreign SOEs when engaging international trade (covering both the goods and services markets)}

This section of the paper covers concerns about competition with foreign SOEs when engaging international trade of goods and services. Respondents were asked to identify whether foreign SOEs involved in international trade (including competition in the SOE's domestic markets) benefit from preferential treatment. The results indicate that an overwhelming number of respondents to the survey consider that "foreign SOEs benefit from preferential treatment by their governments." However, with regard to whether such treatment is more frequently accorded to SOEs versus privately-owned enterprises from the same country, the results indicate a more nuanced picture; with only half of respondents considering that foreign SOEs are "more frequently" accorded such preferential treatment as compared with private competitors (Figure 14).

Preferential treatment can be defined as government measures or actions, which affect costs or prices of commercial enterprises and which are extended only to certain specific enterprises or groups of enterprises, and can be in the form of:

- Grants and other direct payments. This can include policies that support R\&D; environmental and green programmes ${ }^{19}$; general economic development policies (e.g. industrial policy); sector or product-specific economic development policies; and support for the provision of public services; all of which if not provided equally to competitors on the same market could create a non-neutral situation.

- Tax concessions. Tax concessions can often be found in the form of schemes aimed at compensating SOEs for their public services obligations at home (e.g. delivery of postal service or transport services in remote areas which would not be commercially viable); however, if schemes are proportional to the business volume rather than public service obligations themselves this can be seen as a form of preferential treatment.

\footnotetext{
${ }^{19}$ To the extent that they can be considered distortive or only applicable to certain specific enterprises or groups of enterprises. See also OECD (2015g) Policy Guidance for Investment in Clean Energy Infrastructure http://www.oecd.org/daf/inv/investment-policy/CleanEnergyInfrastructure.pdf
} 
Figure 14. Competition with foreign SOEs -Trade concerns

Trade in goods and services

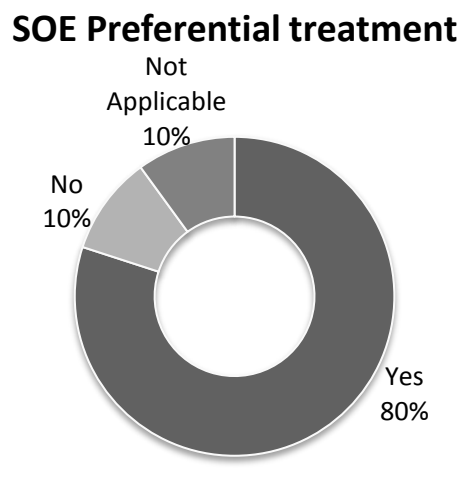

SOE vs POE preferential treatment

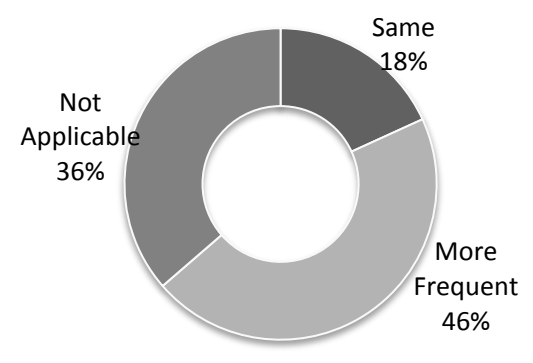

SOE preferential treatment (trade impact)

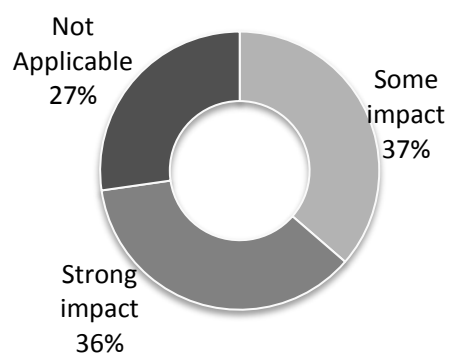

SOE vs POE preferential treatment (observable differences)

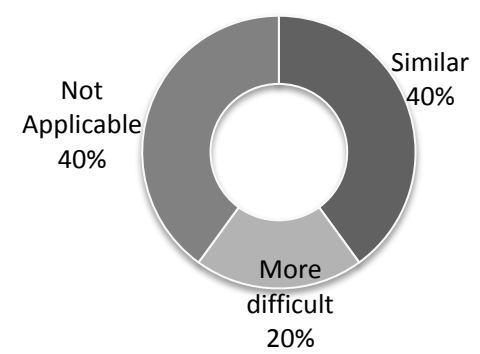

Source: Responses received from the OECD Survey on State-Owned Enterprises in the Global Marketplace (2015)

- In-kind subsidies. This can include preferential access to inputs such as labour, land or infrastructure.

- Concessionary financing/government guarantees. Favourable requirements with respect to rateof-return on capital of SOEs; favourable requirements with respect to dividends of SOEs; direct financial state support (not linked to public service obligations); recapitalisation of SOEs at lower than market rates; provision of credit below the market interest rate; and provision of statebacked guarantees. Preferential financing can be provided through state-owned banks or financial institutions, privately owned banks in the presence of government guarantees, or through other state-owned companies (for example within the same holding).

- Preferential regulatory treatment. These can amount to: simplified procedures to obtain licences or permits; granting of special rights to operate to extract resources; exemptions for application of general laws and regulations; exemptions from regulatory compliance (e.g. environmental or technical specifications); exemptions or non-compliance with information disclosure requirements; unjustified denial of approvals to potential competitors; exemptions from building permits or zoning regulations; and obtaining of grandfather clauses.

- Exemptions from anti-trust enforcement; exemptions from bankruptcy rules. Exemptions from anti-trust enforcement or bankruptcy rules can create opportunities for SOEs to engage in anticompetitive behaviour. For example, it may allow SOEs to generate losses for a long period of time without fear of going bankrupt. However, it should be said that in most countries, with a few 
exceptions, incorporated SOEs are reported not to be exempt from either. SOEs are alleged to be subject to softer enforcement which may reflect a source of concern. [See also OECD Database on Regulations and National Practices in Competitive Neutrality]

- Preferential treatment in public procurement. Preferential access to information about upcoming public procurement contracts and tenders (i.e. technical or other specifications essential for awarding the contract); outright favouritism of SOEs in awarding contracts.

- Price support. Policy measures that can create a gap between domestic market prices and reference prices of a specific commodity.

- Asymmetric access to information. Access to confidential government information; prerogative position in consultations with the government regarding new policies or for public contracts (technical specifications, sanitary rules, environmental policies, laws, taxation initiatives); derogations from financial disclosure and transparency standards, for which information on the competitor is likely to be available.

- Support in the form of commercial diplomacy. Reliance on the government's backing and diplomatic relations to pursue business opportunities, otherwise not commercially possible without such support or not available to competitors. ${ }^{20}$

On the types of preferential treatment that were considered the most problematic with regarding to trade in both the goods and services sectors, the survey asked policy-makers to identify the main types of preferential treatment that can have an impact on competition; and to evaluate the scale of impact, ranging from "strong impact", "some impact" or "no impact". The results can be summarised as follows (Figures $15 \mathrm{a}$ and 15b); but it should be caveated that the impact on competition may vary depending on the markets and sectors; and most respondents more or less agree that, with the exception of price supports, specific forms of preferential treatment can granted equally to SOEs and other companies:

- "Strong impact": In the order of most to least respondents the following issues were considered of "strong" impact: $1^{\text {st }}$ place) grants and other direct payments; preferential regulatory treatment; preferential treatment in public procurement; and price support; $2^{\text {nd }}$ place) tax concessions; inkind subsidies; concessionary financing and government guarantees; $3^{\text {rd }}$ place) exemptions from anti-trust enforcement and bankruptcy results; preferential access to information; and support in the form of commercial diplomacy.

- "Some impact": In the order of most to least respondents the following issues were considered of "some" impact: $1^{\text {st }}$ place) exemptions from anti-trust enforcement and bankruptcy rules; preferential access to information; support in the form of commercial diplomacy; $2^{\text {nd }}$ place) tax concessions; concessionary financing and government guarantees; preferential regulatory treatment; preferential treatment in public procurement; $3^{\text {rd }}$ place) grants and other direct payments; in-kind subsidies; price support. $4^{\text {th }}$ place) limited market access for foreign-owned companies (as specified under "other").

\footnotetext{
${ }^{20}$ Some analysts posit that SOEs can be granted special favours and protections by various host governments which would otherwise not have been made available to comparable private investments. SOEs may also be less reluctant than private competitors to invest in countries with poor business climates, due in part to state's political backing.
} 
Figure 15. Preferential treatment of SOEs - Impact on international trade of goods and services (Part A)

Forms of treatment with most significant impact on competition

International goods markets

International services markets

\section{Grants/direct payments}
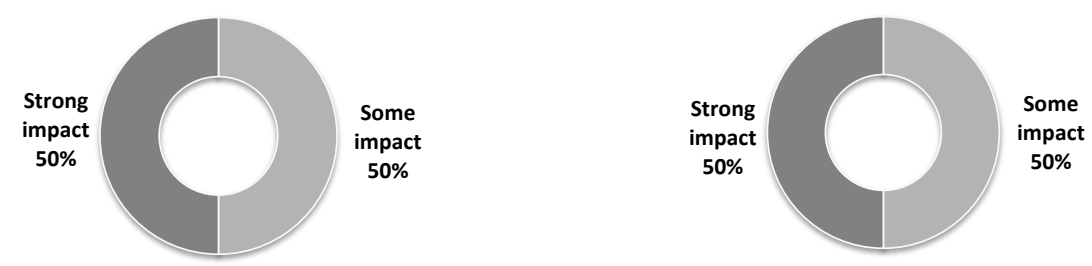

\section{Tax concessions}
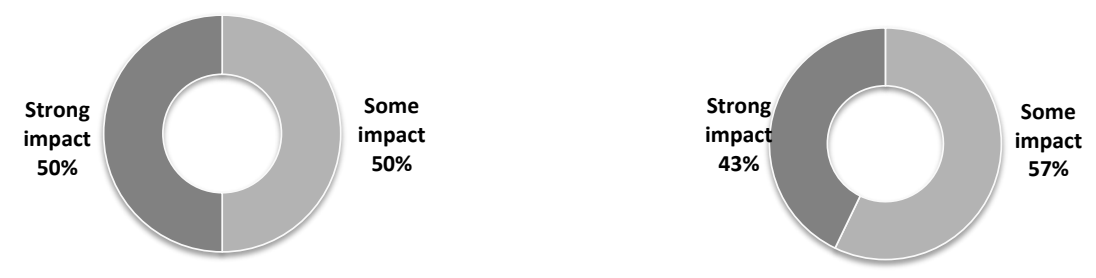

\section{In-kind subsidies}
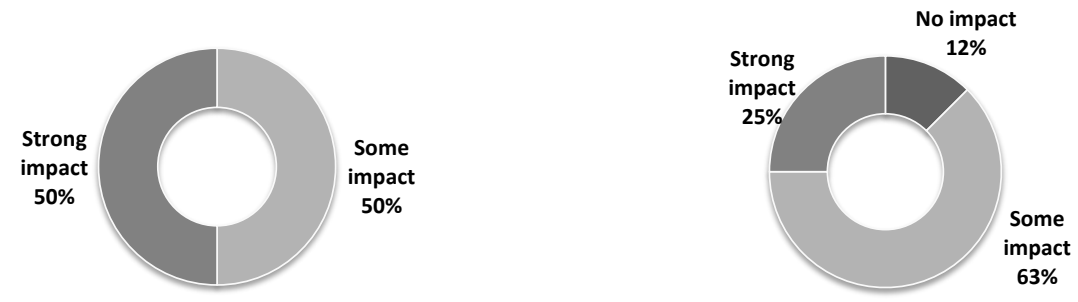

\section{Concessionary financing/guarantees}
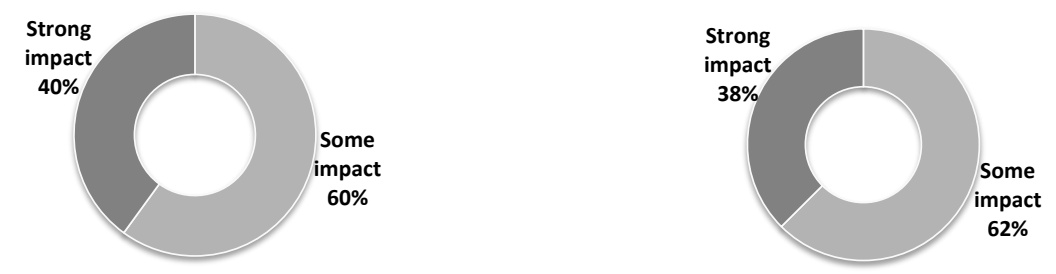

\section{Regulatory treatment}
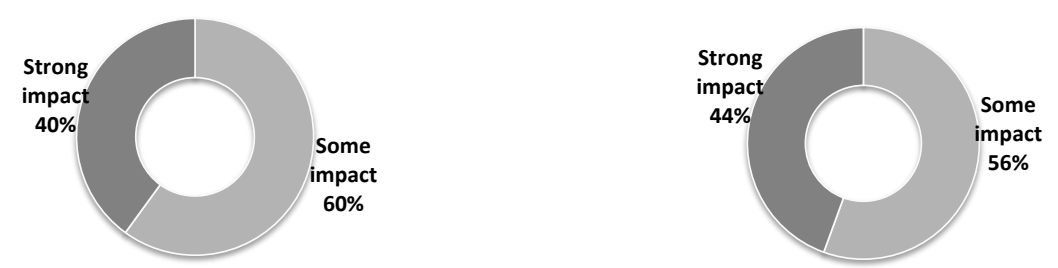
Figure 15. Preferential treatment of SOEs - Impact on international trade of goods and services (Part B, Con't from previous page)

Forms of treatment with most significant impact on competition

International services markets

\section{Exemptions (anti-trust/bankruptcy)}
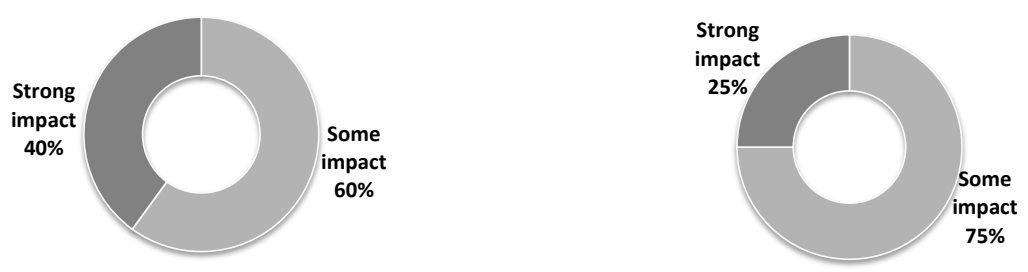

\section{Public procurement}
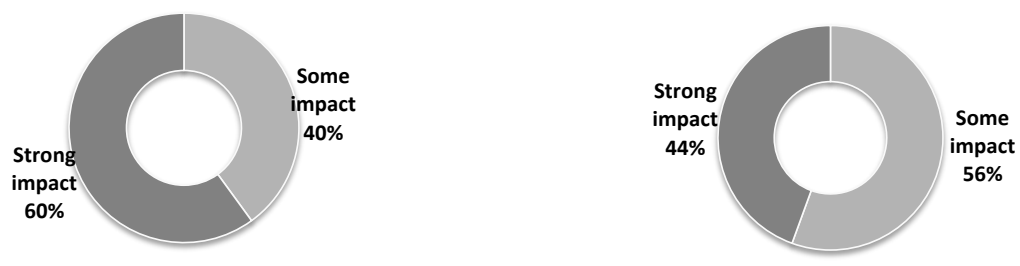

Price support
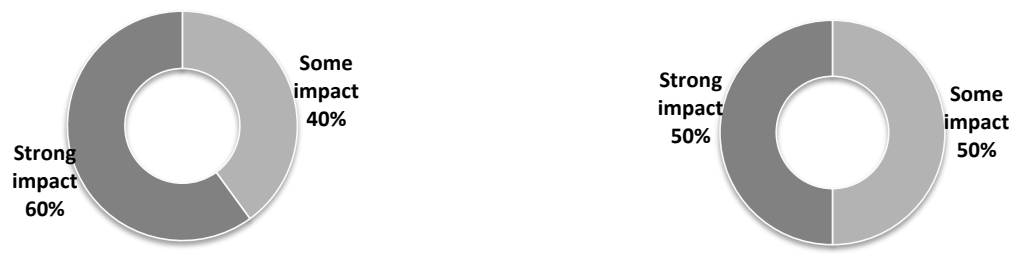

\section{Access to information}
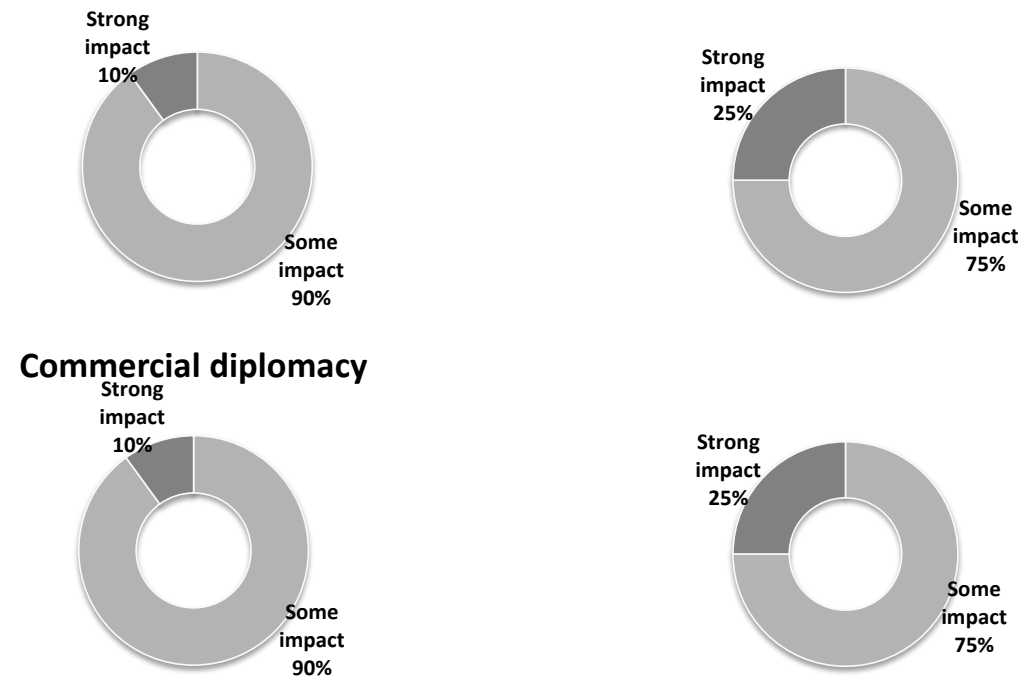

Source: Responses received from the OECD Survey on State-Owned Enterprises in the Global Marketplace (2015) 
Overall the results would seem to corroborate the nature of concerns expressed by the business community in the 2014 OECD Business Survey on State Influence on Competition in International Markets. The main areas of concern being, financial and regulatory forms of support for business community; moreover, tax concessions and in-kind subsidies granted to both state-owned and privately owned companies by foreign governments were reported as having a strong negative impact on sales by the largest number of respondents. Other forms of preferential treatment granted to state-owned competitors with strong reported impact on sales were grants and other direct payments, concessionary financing, government guarantees and preferential regulatory treatment.

Ability to detect preferential treatment for SOEs. A commonly held view is that in the absence of a competitive neutrality-type commitment, preferential treatment provided to SOEs is arguably harder to detect than that for private companies due to the public service objectives that SOEs often carry out, and possibilities for subsidies to be hidden (especially in-kind subsidies or tax concessions or other forms of compensation provided to carry out public service obligations) (see OECD, 2012). However, according to a majority of responding jurisdictions, determination of such preferential treatment is "not observably different" than for companies under private ownership (Figure 15).

Impact on the size and direction of international trade of goods and services. When asked about the impact of preferential treatment of SOEs on the size and direction of international trade of goods and services, over three-quarters of respondents combined indicate that it has a "some" or "strong" impact (Figure 15). Of particular concern under the categories of "some" or "strong" impact, were: i) barriers to the flow of investments (FDI), resulting in long run current account surplus, and surplus in capital accounts, thus distorting international trade; and ii) investments decisions and pricing influenced by preferential treatment. However, respondents further caveated that i) more evidence is needed to evaluate the actual impact of preferential treatment with other factors which may influence SOE internationalisation (e.g. managerial decisions); ii) SOEs may be faced with other requirements (e.g. bureaucratic) that could disadvantage them; iii) as key providers of public services (in electricity, postal, transport, or telecommunications sectors), international trade of goods and services is inevitable and can have an impact on economic development.

Advantages granted by SOEs to other firms. Another commonly held position is the reported use of state-owned enterprises by foreign governments to indirectly grant advantages to competitors. Typically, granting a cheaper loan would constitute an upstream advantage; whereas giving providers access to goods or services at favourable prices would constitute a downstream advantage. According to respondents, both upstream and downstream advantages can "sometimes have impacts on the playing field" by creating artificial competitive advantages for the beneficiary; and may have the effect of limiting the suppliers of goods and services in the marketplace. Respondents further assess that the impact on competition can range from "strong" to "some" impact in both the goods and services markets; with the goods market appearing to be more problematic than the services' market, some examples were provided by respondents as follows: i) preferential access to raw materials or energy; and ii) preferential treatment in the rare earths, bicycle manufacturing and solar panel industries.

As compared with the OECD 2014 Business Survey on State Influence on Competition in International Markets, the business community reported much more prevalent distortions due to preferential treatment upstream in the value chain than downstream. The authors of the survey results note that, "Indeed, 55\% of respondents reported that SOEs were used to lower the prices or facilitate accessibility of inputs while only $30 \%$ reported that they were used to offer more favourable prices or 
procurement terms. ${ }^{21}$ " The authors further flag that in a trade context, this issue can be important for what concerns determining which enterprises can be considered as granting subsidies for WTO cases.

\section{Figure 16. Advantages granted by foreign governments to or via SOEs - Level of government}

\section{A policy perspective}
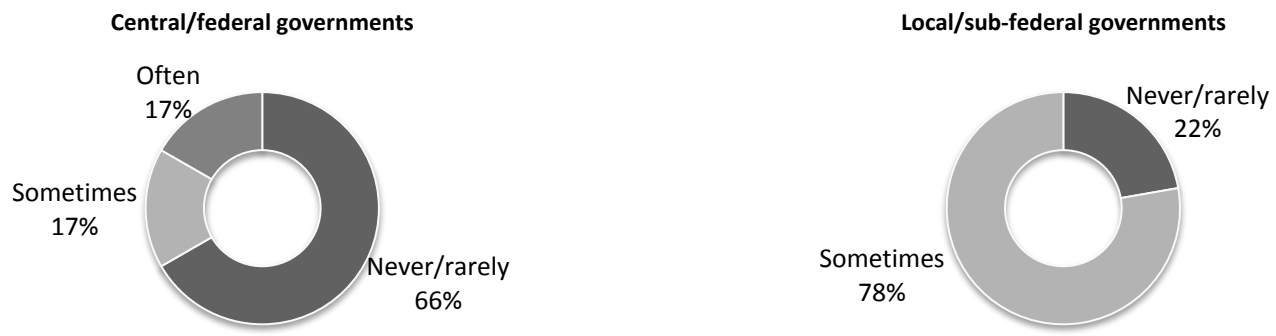

Source: Responses received from the OECD Survey on State-Owned Enterprises in the Global Marketplace.

Figure 17. Advantages granted by foreign governments to competitors - Level of government ${ }^{22}$

A business perspective

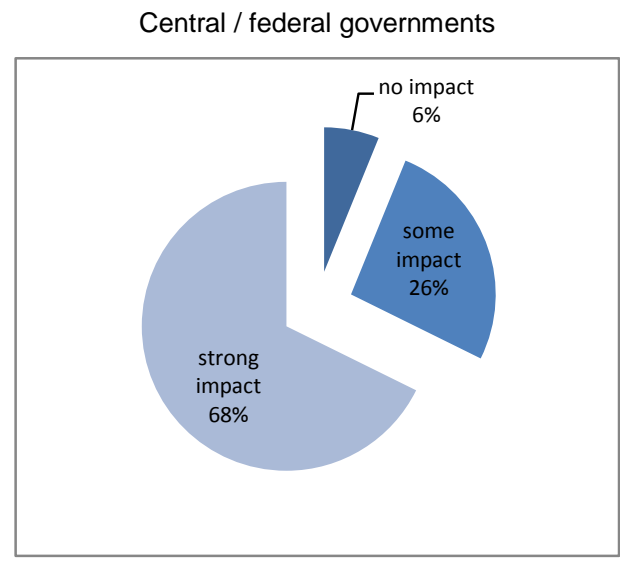

Local / sub-federal governments

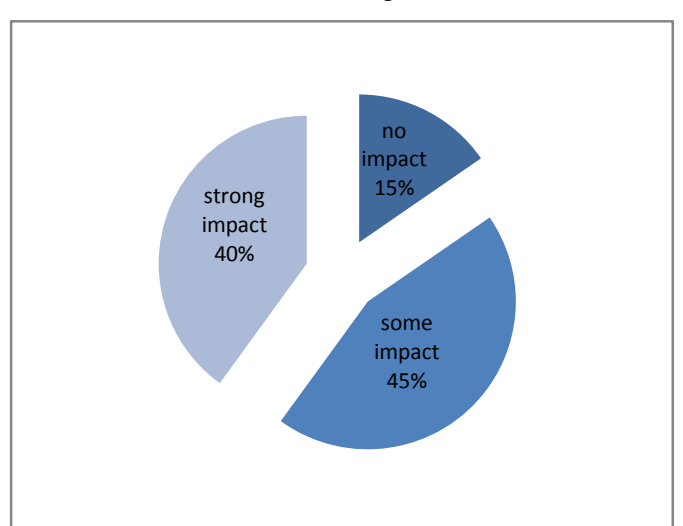

Source: Responses received from the Business Survey on State Influence on Competition in International Markets (OECD, 2015f).

Government ownership and the central/federal or sub-national levels. Survey respondents were asked to identify the levels of government that engage most often in either granting advantages to SOEs or using SOEs to grant advantages to other enterprises. The majority of respondents indicate that local or sub-

21 However, slightly different picture is observed when looking at the results excluding the steel sector. While almost the same share of respondents (29\%) report the provision of preferences by foreign governments through the use of SOEs downstream in a value chain, a lower percentage of respondents $(41 \%)$ indicate that SOEs are used to reduce the prices or facilitate accessibility of inputs (Annex Figure 15). This difference of the results might be explained by the specificity of the steel sector where availability and accessibility of inputs are crucial for production with a further direct impact on output price and its competitiveness on the market.

${ }^{22}$ These results include steel firms. For results excluding response from firms in the steel sector refer to the OECD report cited as Kowalski, P. and K. Perepechay (2015). The following question was asked: What levels of foreign governments grant advantages to competitors with the strongest negative impact on respondents' business? 
federal governments "sometimes" engage in this type of behaviour (Figure 16). Contrasted with results emanating from the 2014 OECD Business Survey on State Influence on Competition in International Markets, the authors assess that "central or federal levels of government are reported to be granting advantages with strong negative impacts on competition more frequently than sub-federal governments, though it is clear that the latter are engaging in discriminatory behaviour as well." (Figure 17) (OECD,2015f) Although the two sets of responses cannot be reconciled, it has been alleged that SOEs operating sub-national level may be subject to less stringent checks and oversights (see also OECD, 2012, which points out challenges in ensuring a level playing field at the sub-national level, which reportedly can go unchecked in the absence of a broad competitive neutrality commitment).

\subsection{Discrimination of SOEs when engaging in international trade (covering both the goods and services markets)}

This sub-section revisits obstacles to SOE internationalisation, with a focus on particular impediments faced by SOEs when engaging in international trade. It relates to section 3.1 discussed above - in that the questions are primarily addressed to government owners of SOEs - but attempts to identify whether SOEs are discriminated against in their trade activities. Obstacles can entail:

- Refusal or higher requirements for approval of SOE FDI;

- Unfavourable post-FDI establishment treatment of SOEs;

- Restricted access to goods and services markets when SOEs are export or importing across borders; and,

- Higher probability of facing trade remedies and litigation in the WTO.

As results indicate, SOEs do not face additional obstacles as compared with private companies when operating in international markets because of their ownerships status. Compared with results under section 3.1 and those covered under section 2, respondents indicate that obstacles faced by SOEs are the same as for other companies.

However, respondents further qualify their answers by indicating that if/when obstacles outlined above are evoked by regulatory authorities of foreign jurisdictions the types of concerns relate to (in the order of respondents): i) pursuit of non-commercial objectives; ii) concerns about corporate governance of SOEs; iii) preferential treatment (regulatory or other) in the domestic marketplace; iv) subsidised crossborder trade; v) subsidised provision of goods or services through subsidised presence abroad. Of least concern was a lack of economic benefit to the host economy in the case of trade-related FDI.

Regarding abating any possible concerns to the country recipient to SOE trade, one respondent noted that transparency is considered fundamental to ensure that SOEs business operations are driven by market considerations and not political ones. Compared with the findings under section 3.1, again the importance placed around transparency and disclosure practices is highlighted to enhance legitimacy of a SOE market participation on its commercial motivations. 


\section{BIBLIOGRAPHY}

Capobianco, A. and H. Christiansen (2011), "Competitive Neutrality and State-Owned Enterprises: Challenges and Policy Options", OECD Corporate Governance Working Papers, No. 1, OECD Publishing, Paris, DOI: http://dx.doi.org/10.1787/5kg9xfgjdhg6-en

Cuervo-Cazzura, Alvaro, et. al. (2014), "Government as Owners: State-Owned Multinational Companies," Journal of International Business Studies, Special Issue on State-Owned Multinational Companies, Vol.45, No.8.

Ding, Yuan; Meyer, Klaus E.; Li, Jing; and Zhuang, Hua (2014). "Overcoming distrust: how SOEs adapt their foreign entries to institutional pressures abroad". Journal of International Business Studies 45, $1005-1028$.

Dobson, Wendy (2014) “China's State-Owned Enterprises and Canada's FDI Policy," University of Calgary SSP Research Papers, Vol. 7, Issue 10, March 2014.

Eden, Lorraine, Miller, Stewart (2004), Distance Matters: Liability of Foreignness, Institutional Distance and Ownership Strategy, in Michael A. Hitt, Joseph L.C. Cheng (ed.) "Theories of the Multinational Enterprise: Diversity, Complexity and Relevance" (Advances in International Management, Volume 16) Emerald Group Publishing Limited, pp.187 - 221.

IWG (2008), "Santiago Principles," International Working Group of Sovereign Wealth Funds, www.iwgswf.org/pubs/eng/santiagoprinciples.pdf.

KPMG and University of Sydney (2014), Demystifying SOE Investment in Australia, Report prepared for the Business Council of Australia.

OECD (2015a) Does state ownership raise additional challenges for investment regulators and owners? Issues for discussion, OECD Internal Working Document.

OECD (2015b), FOI Survey of Investment Policies Related to National Security.

OECD (2015c). "The Policy Landscape for International Investment by Government Controlled Investors: A Fact Finding Survey.” Yuri Shima, OECD Working Papers on International Investment, 2015/01, OECD Publishing, http://dx.doi.org/10.1787/5js7svp0jkns-en.

OECD (2015d) State-Owned Enterprises in the Global Marketplace: A Horizonntal Approach, OECD

OECD (2015e), OECD Guidelines on Corporate Governance of State-Owned Enterprises, 2015 Edition, OECD Publishing, Paris. DOI: http://dx.doi.org/10.1787/9789264244160-en.

OECD (2015f) Business Survey on State Influence on Competition in International Markets, www.oecd.org/tad/tradedev/oecd-business-survey-state-influence-competition-internationalmarkets.htm.

OECD (2015g), Policy Guidance for Investment in Clean Energy Infrastructure : Expanding Access to Clean Energy for Green Growth and Development, OECD Publishing, Paris. DOI : http://dx.doi.org/10.1787/9789264212664-e. 
OECD (2014), OECD Foreign Bribery Report: An Analysis of the Crime of Bribery of Foreign Public Officials, OECD Publishing, Paris. DOI: http://dx.doi.org/10.1787/9789264226616-en.

OECD (2013a), “A Stocktaking of International Investment by State-owned Enterprises and Relevant Elements of National and International Policy Frameworks", unpublished OECD document.

OECD (2012), Competitive Neutrality: Maintaining a Level Playing Field between Public and Private Business, OECD Publishing, Paris. DOI: http://dx.doi.org/10.1787/9789264178953-en.

$\operatorname{OECD}(2011)$ Declaration on International Investment and Multinational Enterprises. www.oecd.org/investment/investment-policy/oecddeclarationanddecisions.htm.

OECD (2009), OECD Guidelines for Recipient Country Investment Policy Related to National Security, www.oecd.org/investment/investment-policy/41807723.pdf.

OECD (2008a). OECD Declaration on Sovereign Wealth Funds and Recipient Country Policies www.oecd.org/investment/investment-policy/oecdguidanceonsovereignwealthfunds.htm.

OECD (2008b). "Protection of 'Critical Infrastructure' and the Role of Investment Policies Relating to National Security". Kathryn Gordon and Maeve Dion, May. OECD Freedom of Investment Roundtables. Available at: www.oecd.org/investment/investment-policy/40700392.pdf.

Kowalski, P. and K. Perepechay (2015), "International Trade and Investment by State Enterprises", OECD Trade Policy Papers, No. 184, OECD Publishing, Paris. DOI: http://dx.doi.org/10.1787/5jirtcr9x6c48-en.

PwC(2015a) CEO pulse: Pulse on state-owned enterprises. www.pwc.com/gx/en/ceo-agenda/pulse/stateowned-enterprises.html.

PwC(2015b) State-Owned Enterprises: Catalysts for public value creation.

Woo, Y.P. (2014), "Chinese lessons: state-owned enterprises and the regulation of foreign investment in Canada," China Economic Journal, Vol. 7, No. 1. 


\section{APPENDIX: SURVEY QUESTIONNAIRE ON STATE-OWNED ENTERPRISES IN THE GLOBAL MARKET PLACE}

This questionnaire aims to guide discussion on concerns related to the cross-border activities of stateowned enterprises (SOEs). Responses to this questionnaire will feed into a report which will:

- identify concerns of host country policy makers when foreign SOEs or foreign controlled companies seek to trade or invest in their jurisdictions;

- Concerns of SOEs (and their owners) when operating abroad.

This questionnaire is being managed by the OECD-hosted Freedom of Investment Roundtable in the context of an OECD project on SOEs in the global marketplace.

\section{Scope of the questionnaire and who can respond:}

The questionnaire is addressed to government authorities responsible for enterprise ownership, competition authorities, investment regulators and trade authorities in addition to departments of government (e.g. ministries of finance and/or industry) with broader responsibility for the enterprise and competition landscape, and/or cross-border trade and investment regulation.

Recipients are invited to complete the questionnaire to the best of their knowledge, fill out parts that relate to their areas, and share the questionnaire with other relevant parts of government. Multiple respondents from the same country/government can access and respond to the questionnaire. The final results of the questionnaire will ensure anonymity.

The questionnaire is divided into three parts:

Part A: Concerns of host country policy-makers when foreign SOEs seek to invest in their jurisdictions Part B: Concerns of SOEs (and their owners) when operating abroad

Part C: Concerns related to international trade of goods and services involving SOEs. 


\section{Part A: Concerns of host country policy-makers when foreign SOEs seek to invest in their jurisdiction}

Part A of the questionnaire addresses concerns of host country policy makers when foreign SOEs seek to operate in their jurisdictions. It is mainly addressed to government authorities responsible for the regulation of international investment.

1. Please check the main types of concerns that arise when foreign SOEs seek to establish themselves in your jurisdiction (check all that applies). For each concern please determine on which scale.

\begin{tabular}{|c|c|c|}
\hline Main issue & Example & Scale of concern \\
\hline National security & $\begin{array}{l}\text { SOEs used for espionage; denial of services or sabotage in } \\
\text { case of conflict; erosion of strategic advantages; acquire } \\
\text { strategic assets }\end{array}$ & Less | Somewhat | Strong \\
\hline Public interest & Lower environmental, health, safety standards & Less | Somewhat | Strong \\
\hline Net economic benefits & Local employment & Less | Somewhat | Strong \\
\hline $\begin{array}{l}\text { Protect national } \\
\text { "champions" }\end{array}$ & Loss of economies of scale; loss of proprietary technologies & Less | Somewhat | Strong \\
\hline $\begin{array}{l}\text { Ad hoc political } \\
\text { intervention }\end{array}$ & $\begin{array}{l}\text { Intervention by the government owner in company } \\
\text { operations, potentially distortive in the case of crisis } \\
\text { response }\end{array}$ & Less | Somewhat | Strong \\
\hline $\begin{array}{l}\text { Competition } \\
\text { enforcement policies }\end{array}$ & $\begin{array}{l}\text { Foreign SOEs not subject to strict completion law } \\
\text { enforcement in home country. Potential for competition } \\
\text { distortions in host country markets. }\end{array}$ & Less | Somewhat | Strong \\
\hline $\begin{array}{l}\text { Maintain a level playing } \\
\text { field }\end{array}$ & $\begin{array}{l}\text { Subsidisation and other benefits (tax exemptions, } \\
\text { favourable access to finance, etc.) at home leading to } \\
\text { "unfair" advantages abroad }\end{array}$ & Less | Somewhat | Strong \\
\hline $\begin{array}{l}\text { Insufficient information } \\
\text { about entrants }\end{array}$ & $\begin{array}{l}\text { SOEs being privy to privileged information; or a general lack } \\
\text { of cross-border transparency on government objectives }\end{array}$ & Less | Somewhat | Strong \\
\hline $\begin{array}{l}\text { "Re-nationalisation" of } \\
\text { privatised firms }\end{array}$ & $\begin{array}{l}\text { SOEs purchasing private companies may run counter the } \\
\text { arguments presented in favour of privatisation }\end{array}$ & Less | Somewhat | Strong \\
\hline SOE governance & $\begin{array}{l}\text { Political appointments at the level of the board or } \\
\text { management }\end{array}$ & Less | Somewhat | Strong \\
\hline Corruption risk & $\begin{array}{l}\text { Risk of involvement in corruption or bribery in other } \\
\text { jurisdictions }\end{array}$ & Less | Somewhat | Strong \\
\hline \multicolumn{3}{|l|}{ Not applicable } \\
\hline Other & If other, please describe your concern: & Less | Somewhat | Strong \\
\hline
\end{tabular}




\section{i) Concerns related to national security ${ }^{23}$}

2. Compared with foreign investment by privately-owned firms, to what extent are foreign SOEs seeking to invest in your jurisdiction considered a threat to national security?

Not a threat | Less of a threat than foreign privately-owned enterprises | Same level of threat Somewhat more of a threat | Much more of a threat | Not applicable

If you do not perceive the same level of threat, please explain why:

3. Are you concerned that foreign SOE ownership of critical infrastructure could pose a direct threat to national security?

Not concerned | Somewhat concerned | Strongly concerned | Not applicable

If concerned, please provide details:

4. Are there concerns that by investing in your jurisdiction foreign SOEs can acquire control over strategic technologies or natural resources in the strategic interest of their government?

No concerns | Some concerns | Strong concerns| Not applicable

If of concern, please provide details.

5. Are there concerns that SOEs may serve as conduits for espionage, e.g. directly via key personnel or through access to national communications networks?

No concerns | Some concerns | Strong concerns | Not applicable

If of concern, please provide details:

6. Please describe any other concerns related to national security:

7. Are foreign SOEs or government-controlled enterprises' investments subject to more intensive monitoring due to national security concerns (even if on a case-by-case basis)?

Yes | No| Not applicable

If yes, please provide details:

\section{ii) Concerns related to competition}

8. Are there concerns about the competitive situation of SOEs investing in your jurisdiction? Please indicate level of concern for each:

23 OECD (2009), OECD Guidelines For Recipient Country Investment Policies Relating to National Security 


\begin{tabular}{|l|l|}
\hline \multicolumn{1}{|c|}{$\begin{array}{c}\text { Concerns about the competitive situation of SOEs in } \\
\text { their home jurisdiction }\end{array}$} & Scale of concern \\
\hline $\begin{array}{l}\text { Preferential financing from state banks or other financial } \\
\text { institutions }\end{array}$ & Less | Somewhat | Strong \\
\hline Outright subsidies & Less | Somewhat | Strong \\
\hline Privileged position in the domestic market & Less | Somewhat | Strong \\
\hline Explicit or implicit guarantees & Less | Somewhat | Strong \\
\hline Regulatory forbearance or exemptions & Less | Somewhat | Strong \\
\hline Preferential access to state information & \\
\hline Not applicable & \\
\hline Other types of preferential treatment. Please describe: & \\
\hline
\end{tabular}

9. If foreign SOEs participate in public procurement and tenders in your country, are they subject to particular requirements or treatment (i.e. different from other bidders)?

Yes | No| Not applicable

If yes, please explain:

10. Are some SOE entrants perceived to benefit from unfair competitive advantages due to their public ownership?

Yes | No | Not applicable

11. If you have answered yes to question 10 , are corrective measures taken?

Yes | No | Not applicable

If yes, please list what types of corrective measures:

12. Do specific competition concerns arise when foreign SOEs enter your jurisdiction (e.g. anti-competitive mergers, cartels, monopolisation or abuses of dominance)?

Yes | No | Not applicable

If yes, please provide details and/or examples:

13. As a general matter, have foreign SOEs in some cases pay higher acquisition premiums than private companies would have paid in like circumstances?

Yes | No | Not applicable

If yes, please provide details and/or examples: 
14. Conversely, are there concerns that foreign SOEs may pay less than normal market value because of undue benefits in its home jurisdiction (e.g. privileged financing, state guarantees or subsidies)?

Yes | No | Not applicable

If yes, please provide details and/or examples:

15. Please describe any other concerns with regards to the competitive situation of foreign SOEs operating or seeking to operate in your jurisdiction:

\section{iii) Legal, regulatory and enforcement issues}

16. Do any of the following apply different to foreign SOEs as opposed to trade/investments by foreign private companies in your jurisdiction? (vis-à-vis competition and other relevant laws and regulations)

\begin{tabular}{|l|c|l|}
\hline \multicolumn{1}{|c|}{ Type } & $\begin{array}{c}\text { Do any of the following apply } \\
\text { differently to foreign SOEs as } \\
\text { opposed to trade/ investments by } \\
\text { foreign non-SOEs in your } \\
\text { jurisdiction } \\
\text { check as applicable }\end{array}$ & If so, please describe \\
\hline Laws/Regulations & $\square$ & \\
\hline Authority and jurisdiction & $\square$ & \\
\hline Investigation powers & $\square$ & \\
\hline Sanctions and remedies & $\square$ & \\
\hline Not applicable. & $\square$ & \\
\hline
\end{tabular}

17. Are there concerns that foreign SOEs be shielded from law enforcement through the invocation of sovereign immunity in your jurisdiction?

\section{No concerns | Some concerns | Strong concerns| Not applicable}

If of concern, please provide details and/or examples:

18. Are there instances where regulators and law enforcers have obtained access to sufficient or insufficient information about foreign SOEs operating in your markets?

No information | Insufficient information | Sufficient information| Not applicable

If information is insufficient, please describe what could be useful:

19. Do you rely on any of the following to obtain information on foreign SOE operations (check as it applies):

Voluntary disclosure by SOEs/government owners

Cross-jurisdictional co-operation 
A combination of both

Not applicable

None of the above, please explain:

20. Please describe any other concerns regarding legal, regulatory and enforcement issues:

iv) Transparency and governance of SOEs

21. What aspects of an SOE's governance might or have given rise to concerns that would influence the decision to allow a foreign SOE to operate or invest in your jurisdiction?

\begin{tabular}{|l|c|}
\hline \multicolumn{1}{|c|}{ Concerns about SOE governance } & Scale of concern \\
\hline Independence of corporate management & Less | Somewhat | Strong \\
\hline Independence of board members & Less | Somewhat | Strong \\
\hline Political interference in decision-making & Less | Somewhat | Strong \\
\hline Quality of financial and non-financial information & Less | Somewhat | Strong \\
\hline $\begin{array}{l}\text { Risks of being involved in cases involving foreign } \\
\text { corrupt practices }\end{array}$ & Less | Somewhat | Strong \\
\hline Not applicable & \multicolumn{2}{|l}{} \\
\hline Other, please describe: & \\
\end{tabular}

22. Does access to information on the transparency and governance of SOEs important for influencing the decision to allow a foreign SOE to invest or operate in your jurisdiction? (Check all that apply)

Ownership structures

Corporate governing bodies

State ownership policy

Company-specific objectives

Annual Reports

Not applicable

Other, please describe:

Please describe any other concerns regarding transparency and governance:

End of part $A$ 


\section{Part B: Concerns of SOEs (and their owners) when operating abroad}

Part B of the questionnaire focuses on impediments to and benefits of SOE cross-border activity (either via international investment or trade). It is mainly addressed to government authorities responsible for the oversight of state-owned enterprises.

\section{i.) Impediments to trade and investment by SOEs}

1. Please describe some of the concerns that are faced by SOEs from your jurisdiction when operating abroad. Are these concerns specific to SOEs? (Check all that apply)

\begin{tabular}{|c|c|c|c|}
\hline Concerns & Scale of concern & $\begin{array}{l}\text { Is this specific } \\
\text { to SOEs? }\end{array}$ & $\begin{array}{l}\text { List countries } \\
\text { where this may } \\
\text { be applicable }\end{array}$ \\
\hline $\begin{array}{l}\text { Treatment in investment review } \\
\text { processes }\end{array}$ & Less | Somewhat | Strong & Yes | No & \\
\hline $\begin{array}{l}\text { Restrictions imposed by investment } \\
\text { or trade agreements }\end{array}$ & Less | Somewhat | Strong & Yes | No & \\
\hline $\begin{array}{l}\text { Ability to trade with subsidiaries } \\
\text { subsequent to entry }\end{array}$ & Less | Somewhat | Strong & Yes | No & \\
\hline $\begin{array}{l}\text { Treatment in administrative and } \\
\text { regulatory processes }\end{array}$ & Less | Somewhat | Strong & Yes | No & \\
\hline $\begin{array}{l}\text { Specific industry restrictions, such as } \\
\text { thresholds and limits on foreign } \\
\text { ownership }\end{array}$ & Less | Somewhat | Strong & Yes | No & \\
\hline $\begin{array}{l}\text { Treatment in procurement } \\
\text { processes }^{25}\end{array}$ & Less | Somewhat | Strong & Yes | No & \\
\hline $\begin{array}{l}\text { Treatment under competition laws } \\
\text { and policies }\end{array}$ & Less | Somewhat | Strong & Yes | No & \\
\hline $\begin{array}{l}\text { Institutional factors (working with } \\
\text { local governments and communities, } \\
\text { trade unions) }\end{array}$ & Less | Somewhat | Strong & Yes | No & \\
\hline Negative media coverage & Less | Somewhat | Strong & Yes | No & \\
\hline $\begin{array}{l}\text { Ideological, cultural, language } \\
\text { barriers }\end{array}$ & Less | Somewhat | Strong & Yes | No & \\
\hline Not applicable & & & \\
\hline
\end{tabular}

24 E.g. Acquiring licences, permits, or visa; conforming to environmental standards or industry specifications)

25 E.g. Restrictions in place that may hinder foreign SOE participation (local content requirements, history of previous contracts, requirements for technology transfer)

26 E.g. Merger or cartel regulations, anti-monopoly reviews, etc. 
2. If foreign jurisdictions entertain serious concerns about the objectives of your SOEs' business transactions, do you attribute them to:

\begin{tabular}{|l|c|l|}
\hline $\begin{array}{c}\text { Do any of the following apply to investments by } \\
\text { SOEs from your jurisdiction? }\end{array}$ & $\begin{array}{c}\text { Is this a concern? } \\
\text { (check all that apply) }\end{array}$ & $\begin{array}{c}\text { How do you } \\
\text { address this } \\
\text { concern? }\end{array}$ \\
\hline $\begin{array}{l}\text { Political unease about the motivations of your } \\
\text { company or by the government as a shareholder }\end{array}$ & $\square$ & \\
\hline $\begin{array}{l}\text { Perceptions by privately-owned companies in the host } \\
\text { country that the SOE has a competitive advantage }\end{array}$ & $\square$ & \\
\hline $\begin{array}{l}\text { Worries by labour groups that foreign SOEs can } \\
\text { threaten domestic jobs }\end{array}$ & $\square$ & \\
\hline $\begin{array}{l}\text { General reputational issues with investment from your } \\
\text { country or from foreign governments more generally }\end{array}$ & $\square$ & \\
\hline General concerns about SOE efficiency. & $\square$ & \\
\hline Not applicable & & \\
\hline Other, please describe: & $\square$ & \\
\hline
\end{tabular}

3. Does it help to provide access to information on any of the below to positively influence host countries regarding your trade and/or investment objectives?

\begin{tabular}{|l|c|}
\hline \multicolumn{1}{|c|}{ Access to information on } & Scale of helpfulness \\
\hline Commercial objectives & Less | Somewhat | Very \\
\hline $\begin{array}{l}\text { Governance structures (board composition, board } \\
\text { appointments) }\end{array}$ & Less | Somewhat | Very \\
\hline Ownership mechanisms (ownership entity) & Less | Somewhat | Very \\
\hline Ownership policy (overall and company-specific) & Less | Somewhat | Very \\
\hline $\begin{array}{l}\text { Transparency and disclosure practices (financial and } \\
\text { non-financial disclosure) }\end{array}$ & Less | Somewhat | Very \\
\hline Not applicable & \\
\hline Other, please describe: & \\
\hline
\end{tabular}


4. Are the dispute settlement mechanisms of international trade and investment treaties that your jurisdiction is party to fully applicable in the case of SOEs?

$$
\begin{aligned}
& \text { Yes | No | Not applicable } \\
& \text { If yes, please provide details and/or examples: }
\end{aligned}
$$

5. Have there been cases disqualified from such mechanisms and dealt with on a state-to-state rather than investor-to-state basis?

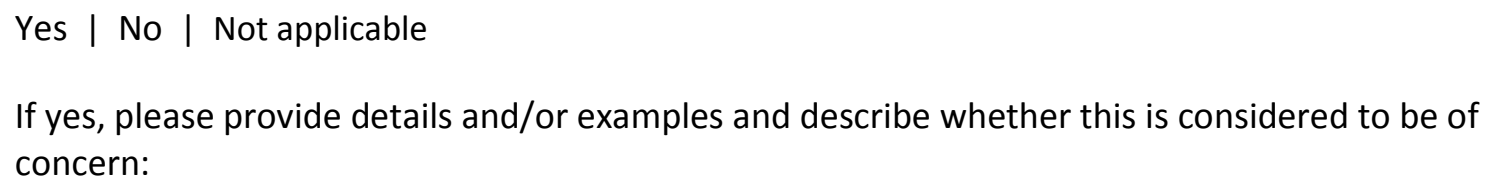

If yes, please provide details and/or examples and describe whether this is considered to be of concern:

\section{ii.) Benefits of cross-border trade and investment by SOEs}

6. What are the main goals behind cross-border trade and investment by SOEs domiciled in your

\begin{tabular}{|c|c|c|}
\hline Goal of cross-border trade and investment & $\begin{array}{l}\text { Scale of relevancy to SOEs } \\
\text { domiciled in your jurisdiction }\end{array}$ & Was the outcome positive? \\
\hline Profit motivation & Less | Somewhat | Strong & No | Somewhat | Very \\
\hline $\begin{array}{l}\text { Internationalisation strategy (ability to compete } \\
\text { internationally) }\end{array}$ & Less | Somewhat | Strong & No | Somewhat | Very \\
\hline $\begin{array}{l}\text { Opportunistic investment motivated by post-crisis } \\
\text { environment. }\end{array}$ & Less | Somewhat | Strong & No | Somewhat | Very \\
\hline Commercial/industry-specific factors & Less | Somewhat | Strong & No | Somewhat | Very \\
\hline Secure access to resources & Less | Somewhat | Strong & No | Somewhat | Very \\
\hline Acquire international management/know-how & Less | Somewhat | Strong & No | Somewhat | Very \\
\hline Acquiring/projecting technologies & Less | Somewhat | Strong & No | Somewhat | Very \\
\hline Building up business reputation & Less | Somewhat | Strong & No | Somewhat | Very \\
\hline Building brand name & Less | Somewhat | Strong & No | Somewhat | Very \\
\hline $\begin{array}{l}\text { Favourable business environment/industry } \\
\text { support in other jurisdictions }\end{array}$ & Less | Somewhat | Strong & No | Somewhat | Very \\
\hline Building partnerships at home for markets abroad & Less | Somewhat | Strong & No | Somewhat | Very \\
\hline Not applicable & & \\
\hline
\end{tabular}
jurisdiction? Has the outcome generally been positive? 
7. What do you perceive to be the benefits of foreign trade and investment by SOEs domiciled in your country?

\begin{tabular}{|l|l|}
\hline & Scale of benefits \\
\hline Provide infrastructure or other basic services & None | Some | Many \\
\hline Provide additional capital & None | Some | Many \\
\hline Creation of employment & None | Some | Many \\
\hline Rescuing ailing industries & None | Some | Many \\
\hline Development of new industries & None | Some | Many \\
\hline Help develop value chains in host country & None | Some | Many \\
\hline Not applicable & \\
\hline Other, please describe: & \\
\hline
\end{tabular}

8. Please describe any efforts that SOEs from your jurisdiction have made to raise awareness of their willingness to act as good corporate citizens and conform to common disciplines and instruments that enhance responsible business conduct. Has this facilitated SOE investment?

\section{Part C. Concerns related to international trade of goods and services involving SOEs}

Part $\mathrm{C}$ to the questionnaire focuses on international trade of goods and services involving either cross-border exports and imports of goods and services or their provision through commercial presence abroad. In this sense it abstracts from obstacles or incentives to SOEs' international investment per se (they are covered in Section A of the questionnaire) but covers issues related to goods and services trade that may be linked to such international investment (e.g. FDI-related restrictions to services trade)..

\section{i.) Concerns about competition with foreign SOEs when engaging in international trade of goods and services}

1. In your view, do foreign SOEs involved in international trade of goods and services (including competition in SOEs' domestic markets) benefit from preferential treatment ${ }^{27}$ by their governments?

\section{Yes | No| Not applicable}

2. Do foreign SOEs benefit from such preferential treatment more frequently than privately-owned enterprises from the same country?

Less frequent | Same | More frequent | Not applicable

27 Preferential treatment is defined as government measures or actions, which affect costs or prices of commercial enterprises and which are extended only to certain specific enterprises or groups of enterprises. 
3. Are there observable differences in the determination of such preferential treatment depending on the ownership of the beneficiary company? If so, is such determination more difficult when an SOE is involved?

Similar | More difficult | Not applicable

If more difficult, please explain why:

4. Does preferential treatment of SOEs influence the size and direction of international trade of goods or services?

No significant impact | Some impact | Strong impact | Not applicable

If some or strong impact, please provide more details:

5. Which forms of preferential treatment of SOEs by foreign governments have the most significant impact on competition in international goods markets? Is such treatment specific to SOEs, or similar for SOEs and POEs?

\begin{tabular}{|c|c|c|}
\hline $\begin{array}{c}\text { Type of preferential } \\
\text { treatment }\end{array}$ & Severity of impact on competition & SOE-specificity \\
\hline $\begin{array}{l}\text { Grants and other direct } \\
\text { payments }\end{array}$ & No impact | Some impact | Strong impact & $\begin{array}{c}\text { Specific to SOEs | Similar for } \\
\text { SOEs and POEs }\end{array}$ \\
\hline Tax concessions & No impact | Some impact | Strong impact & $\begin{array}{c}\text { Specific to SOEs / Similar for } \\
\text { SOEs and POEs }\end{array}$ \\
\hline In-kind subsidies ${ }^{28}$ & No impact | Some impact | Strong impact & $\begin{array}{c}\text { Specific to SOEs | Similar for } \\
\text { SOEs and POEs }\end{array}$ \\
\hline $\begin{array}{l}\text { Concessionary financing and } \\
\text { government guarantees }\end{array}$ & No impact | Some impact | Strong impact & $\begin{array}{c}\text { Specific to SOEs / Similar for } \\
\text { SOEs and POEs }\end{array}$ \\
\hline $\begin{array}{l}\text { Preferential regulatory } \\
\text { treatment }\end{array}$ & No impact | Some impact | Strong impact & $\begin{array}{c}\text { Specific to SOEs | Similar for } \\
\text { SOEs and POEs }\end{array}$ \\
\hline $\begin{array}{l}\text { Exemptions from antitrust } \\
\text { enforcement (competition } \\
\text { laws) and bankruptcy rules }\end{array}$ & No impact | Some impact | Strong impact & $\begin{array}{c}\text { Specific to SOEs / Similar for } \\
\text { SOEs and POEs }\end{array}$ \\
\hline $\begin{array}{l}\text { Preferential treatment in } \\
\text { public procurement }\end{array}$ & No impact | Some impact | Strong impact & $\begin{array}{c}\text { Specific to SOEs / Similar for } \\
\text { SOEs and POEs }\end{array}$ \\
\hline Price support & No impact | Some impact | Strong impact & $\begin{array}{c}\text { Specific to SOEs / Similar for } \\
\text { SOEs and POEs }\end{array}$ \\
\hline $\begin{array}{l}\text { Preferential access to } \\
\text { information }\end{array}$ & No impact | Some impact | Strong impact & $\begin{array}{c}\text { Specific to SOEs | Similar for } \\
\text { SOEs and POEs }\end{array}$ \\
\hline $\begin{array}{l}\text { Support in form of commercial } \\
\text { diplomacy }\end{array}$ & No impact | Some impact | Strong impact & $\begin{array}{c}\text { Specific to SOEs | Similar for } \\
\text { SOEs and POEs }\end{array}$ \\
\hline Not applicable & & \\
\hline
\end{tabular}


6. Which forms of preferential treatment of SOEs by foreign governments have the most significant impact on competition in international services markets?

\begin{tabular}{|c|c|c|}
\hline Type of preference & $\begin{array}{l}\text { Severity of impact on } \\
\text { competition }\end{array}$ & SOE-specificity \\
\hline Grants and other direct payments & $\begin{array}{c}\text { No impact | Some impact | Strong } \\
\text { impact }\end{array}$ & $\begin{array}{c}\text { Specific to SOEs | Similar for SOEs } \\
\text { and POEs }\end{array}$ \\
\hline Tax concessions & $\begin{array}{c}\text { No impact | Some impact | Strong } \\
\text { impact }\end{array}$ & $\begin{array}{c}\text { Specific to SOEs | Similar for SOEs } \\
\text { and POEs }\end{array}$ \\
\hline In-kind subsidies ${ }^{29}$ & $\begin{array}{c}\text { No impact | Some impact | Strong } \\
\text { impact }\end{array}$ & $\begin{array}{c}\text { Specific to SOEs | Similar for SOEs } \\
\text { and POEs }\end{array}$ \\
\hline $\begin{array}{l}\text { Concessionary financing and } \\
\text { government guarantees }\end{array}$ & $\begin{array}{c}\text { No impact | Some impact | Strong } \\
\text { impact }\end{array}$ & $\begin{array}{c}\text { Specific to SOEs | Similar for SOEs } \\
\text { and POEs }\end{array}$ \\
\hline Preferential regulatory treatment & $\begin{array}{c}\text { No impact | Some impact | Strong } \\
\text { impact }\end{array}$ & $\begin{array}{c}\text { Specific to SOEs | Similar for SOEs } \\
\text { and POEs }\end{array}$ \\
\hline $\begin{array}{l}\text { Exemptions from antitrust } \\
\text { enforcement (competition laws) and } \\
\text { bankruptcy rules }\end{array}$ & $\begin{array}{c}\text { No impact | Some impact | Strong } \\
\text { impact }\end{array}$ & $\begin{array}{c}\text { Specific to SOEs | Similar for SOEs } \\
\text { and POEs }\end{array}$ \\
\hline $\begin{array}{l}\text { Preferential treatment in public } \\
\text { procurement }\end{array}$ & $\begin{array}{c}\text { No impact | Some impact | Strong } \\
\text { impact }\end{array}$ & $\begin{array}{c}\text { Specific to SOEs | Similar for SOEs } \\
\text { and POEs }\end{array}$ \\
\hline Price support & $\begin{array}{c}\text { No impact | Some impact | Strong } \\
\text { impact }\end{array}$ & $\begin{array}{c}\text { Specific to SOEs | Similar for SOEs } \\
\text { and POEs }\end{array}$ \\
\hline Preferential access to information & $\begin{array}{c}\text { No impact | Some impact | Strong } \\
\text { impact }\end{array}$ & $\begin{array}{c}\text { Specific to SOEs | Similar for SOEs } \\
\text { and POEs }\end{array}$ \\
\hline $\begin{array}{l}\text { Support in form of commercial } \\
\text { diplomacy }\end{array}$ & $\begin{array}{c}\text { No impact | Some impact | Strong } \\
\text { impact }\end{array}$ & $\begin{array}{c}\text { Specific to SOEs | Similar for SOEs } \\
\text { and POEs }\end{array}$ \\
\hline \multicolumn{3}{|l|}{ Not applicable } \\
\hline Other, please describe: If possible, & de some details and examples: & \\
\hline
\end{tabular}

7. Are SOEs themselves used by governments to grant advantages to other internationally active enterprises, private or state-owned?

\section{Never or rarely | Sometimes | Often | Not applicable}

If sometimes or often, what are the main forms of advantages extended by SOEs to other enterprises?

\begin{tabular}{|c|c|}
\hline Advantage & Frequency \\
\hline Providing advantage upstream (e.g. provision of & Never or rarely | Sometimes | Often \\
\hline
\end{tabular}

29 E.g. provision of goods and services on preferential terms (including labour, land and infrastructure) 
cheaper inputs into production, including cost of

finance)

Providing advantage downstream (e.g. more

favourable prices or procurement conditions)

Never or rarely | Sometimes | Often

Not applicable

8. What advantages involving SOEs have the strongest impact on international competition?

\begin{tabular}{|l|l|}
\hline \multicolumn{1}{|c|}{ Advantage } & Severity of impact on competition \\
\hline \multicolumn{1}{|c|}{ Goods markets } \\
\hline $\begin{array}{l}\text { Granted to SOEs (e.g. subsidies or other form of } \\
\text { preferential treatment granted directly to SOEs) }\end{array}$ & No impact | Some impact | Strong impact \\
\hline $\begin{array}{l}\text { Conveyed by SOEs (e.g. provision of cheaper inputs or } \\
\text { more favourable procurement conditions afforded by }\end{array}$ & No impact | Some impact | Strong impact \\
\hline \begin{tabular}{l|l|} 
SOEs to other firms) \\
\hline Not applicable
\end{tabular} & No impact | Some impact | Strong impact \\
\hline $\begin{array}{l}\text { Granted to SOEs (e.g. subsidies or other form of } \\
\text { preferential treatment granted directly to SOEs) }\end{array}$ & No impact | Some impact | Strong impact \\
\hline $\begin{array}{l}\text { Conveyed by SOEs (e.g. provision of cheaper inputs or } \\
\text { more favourable procurement conditions afforded by }\end{array}$ & SOEs to other firms) \\
\hline \begin{tabular}{l} 
Not applicable \\
\hline
\end{tabular}
\end{tabular}

If possible please explain and provide examples:

9. What levels of government engage most often in either granting advantages to SOEs or using SOEs to convey advantages to other enterprises?

\begin{tabular}{|l|c|}
\hline \multicolumn{1}{|c|}{ Level of government } & Frequency \\
\hline Central / federal government & Never or rarely | Sometimes | Often \\
\hline Local / sub-federal governments & Never or rarely | Sometimes | Often \\
\hline Not applicable & \\
\hline
\end{tabular}

\section{ii.) Concerns about discrimination of domestic SOEs when engaging in international trade of goods and services}

11. In your view, do you country's SOEs face additional obstacles when operating in international markets uniquely because of their state ownership status? $?^{30}$

Yes | No | Not applicable 
If yes, what forms do these additional obstacles take?

\begin{tabular}{|l|l|}
\hline \multicolumn{1}{|c|}{ Obstacles } & \multicolumn{1}{|c|}{ Frequency } \\
\hline $\begin{array}{l}\text { Refusal of, or higher requirements for, approval of SOE FDI used } \\
\text { to deliver goods or services in foreign markets }\end{array}$ & Never or rarely | Sometimes | Often \\
\hline $\begin{array}{l}\text { Unfavourable post-FDI establishment treatment of SOEs by } \\
\text { foreign authorities (e.g. burdensome regulation, frequent } \\
\text { controls) }\end{array}$ & Never or rarely | Sometimes | Often \\
\hline $\begin{array}{l}\text { More restricted access to goods and services markets when } \\
\text { SOEs are exporting or importing across-borders (i.e. without } \\
\text { foreign establishment) }\end{array}$ & Never or rarely | Sometimes | Often \\
\hline $\begin{array}{l}\text { Higher probability of facing trade remedies (e.g. countervailing } \\
\text { duties, anti-dumping and safeguards) and litigation in the WTO }\end{array}$ & Never or rarely | Sometimes | Often \\
\hline Not applicable & \\
\hline Other, please describe: & Never or rarely | Sometimes | Often \\
\hline
\end{tabular}

12. What are they the key reasons given by foreign authorities imposing these obstacles on SOEs' international trade of goods and services?

\begin{tabular}{|l|l|}
\hline \multicolumn{1}{|c|}{ Concerns evoked } & \multicolumn{1}{|c|}{ Frequency } \\
\hline Subsidised cross-border trade & Never or rarely | Sometimes | Often \\
\hline $\begin{array}{l}\text { Subsidised provision of goods or services through subsidised } \\
\text { commercial presence abroad (i.e. FDI) }\end{array}$ & Never or rarely | Sometimes | Often \\
\hline $\begin{array}{l}\text { Other forms of preferential treatment (e.g. preferential } \\
\text { regulatory treatment or monopolistic position of SOEs in the } \\
\text { domestic market) }\end{array}$ & Never or rarely | Sometimes | Often \\
\hline $\begin{array}{l}\text { Pursuit of non-commercial objectives (e.g. strategic acquisition } \\
\text { of technology or natural resources) }\end{array}$ & Never or rarely | Sometimes | Often \\
\hline $\begin{array}{l}\text { Lack of economic benefit to the host economy in the case of } \\
\text { trade-related FDI }\end{array}$ & Never or rarely | Sometimes | Often \\
\hline $\begin{array}{l}\text { Concerns about corporate governance of SOEs including } \\
\text { transparency }\end{array}$ & Never or rarely | Sometimes | Often \\
\hline Not applicable. & \\
\hline Other, please describe: & \\
\hline
\end{tabular}

13. Please describe any additional concerns bearing on international trade of goods and services involving SOEs or state-controlled companies?

-End of survey- 


\title{
OECD Corporate Governance Working Papers
}

http://www.oecd.org/daf/ca/oecdcorporategovernanceworkingpapers.htm

\author{
Stocktaking of Anti-Corruption and Business Integrity Measures for \\ $\mathrm{N}^{\mathrm{o}} 18 \quad 1$ Sep 2015 Southern African SOEs \\ Mary Crane-Charef \\ How is corporate governance in Japan changing: Developments in listed \\ $\mathrm{N}^{\mathrm{o}} 17 \quad 7$ Aug 2015 companies and roles of institutional investors \\ Ryoko Ueda \\ $\mathrm{N}^{\mathrm{o}} 1612$ Feb $2015 \frac{\text { Corporate Bonds, Bondholders and Corporate Governance }}{\text { Serdar Çelik, Gül Demirtas and Mats Isaksson }}$ \\ Corporate Governance Enforcement in the Middle East and North Africa: \\ $\mathrm{N}^{\mathrm{o}} 1530$ Sep 2014 Evidence and Priorities \\ Alissa Amico \\ State-Invested Enterprises in the Global Marketplace: Implications for a \\ $\mathrm{N}^{\mathrm{o}} 1423$ Jul 2014 Level Playing Field \\ Hans Christiansen, Yunhee Kim \\ State-Owned Enterprise Governance: A Stocktaking of Reforms and \\ $\mathrm{N}^{\mathrm{o}} 1315$ Jan 2014 Challenges in Southern Africa \\ Sara Sultan Balbuena \\ Colombian SOEs: A Review Against the OECD Guidelines on Corporate \\ $\mathrm{N}^{\mathrm{o}} 123$ Dec 2013 Governance of State-Owned Enterprises \\ Héctor Lehuedé \\ $\mathrm{N}^{\mathrm{o}} 113$ Dec 2013 Institutional Investors as Owners: Who are they and what do they do? \\ Serdar Çelik, Mats Isaksson \\ No 1011 Jul 2013 Making Stock Markets Work to Support Economic Growth \\ David Weild, Edward Kim, Lisa Newport \\ No 911 Jul 2013 Disclosure of Beneficial Ownership and Control in Indonesia \\ Fianna Jurdant \\ N 819 Apr 2013 Who Cares? Corporate Governance in Today's Equity Markets \\ Mats Isaksson, Serdar Çelik \\ Beneficial Ownership and Control: A Comparative Study - Disclosure, \\ $\mathrm{N}^{\circ} 7 \quad 18$ Jan 2013 Information and Enforcement \\ Erik P.M. Vermeulen \\ Balancing Commercial and Non-Commercial Priorities of State-Owned \\ $\mathrm{N}^{\circ} 6 \quad 18$ Jan 2013 Enterprises \\ Hans Christiansen \\ $N^{\circ} 51$ Aug 2011 The Size and Composition of the SOE Sector in OECD Countries \\ Hans Christiansen \\ Competitive Neutrality and State-Owned Enterprises in Australia: Review \\ $\mathrm{N}^{\circ} 41$ Aug 2011 of Practices and their Relevance for Other Countries \\ Matthew Rennie, Fiona Lindsay \\ N³ 1 Aug 2011 The Exercise of Shareholder Rights: Country Comparison of Turnout and


$\underline{\text { Dissent }}$

Paul Hewitt

$\mathrm{N}^{\circ} 2 \quad 1$ May 2011 Enhancing the Role of the Boards of Directors of State-Owned Enterprises W. Richard Frederick

$\mathrm{N}^{\circ} 11$ May 2011 Competitive Neutrality and State-Owned Enterprises

Antonio Capobianco, Hans Christiansen 
